\title{
Detection of Human Papillomavirus Infection in Oral Cancers reported at Dental Facility: Assessing the Utility of FFPE tissues
}

\section{Gaurav Verma}

ICMR: Indian Council of Medical Research

Nikita Aggarwal

University of Delhi

Abhishek Tyagi

Wake Forest University School of Medicine

Kanchan Vishnoi

ICPO: National Institute of Cancer Prevention and Research

Mohit Jadli

University of Delhi

Tejveer Singh

University of Delhi

Ankit Goel

Subharti Medical College

Durgatosh Pandey

AllMS: All India Institute of Medical Sciences

Ankita Sharma

Lady Hardinge Medical College

Kiran Agarwal

Lady Hardinge Medical College

Urmi Sarkar

Rajiv Gandhi Cancer Institute and Research Centre

Dinesh Chandra Doval

Rajiv Gandhi Cancer Institute and Research Centre

Shashi Sharma

ICMR: Indian Council of Medical Research

Ravi Mehrotra

ICMR: Indian Council of Medical Research

Sukh Mahendra Singh

Banaras Hindu University

Alok Chandra Bharti ( $\nabla$ alokchandrab@yahoo.com ) 


\section{Research Article}

Keywords: Oral cancer, human papillomavirus, formalin-fixed paraffin-embedded, xylene-free DNA isolation, dental hospital

Posted Date: August 3rd, 2021

DOl: https://doi.org/10.21203/rs.3.rs-767234/v1

License: (a) (i) This work is licensed under a Creative Commons Attribution 4.0 International License. Read Full License

Version of Record: A version of this preprint was published at Medical Oncology on November 18th, 2021. See the published version at https://doi.org/10.1007/s12032-021-01608-5. 


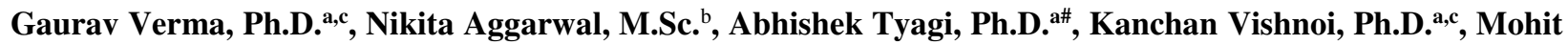
Jadli, M.Sc. ${ }^{b}$, Tejveer Singh, M.Sc. ${ }^{b}$, Ankit Goel, MDS ${ }^{d}$, Durgatosh Pandey, M.Ch. ${ }^{e}$, Ankita Sharma, MD, Kiran Agarwal, MD ${ }^{\mathrm{f}}$, Urmi Sarkar, Ph.D.g, Dinesh Chandra Doval, MD ${ }^{\mathrm{g}}$, Shashi Sharma, Ph.D. ${ }^{\mathrm{a}}$, Ravi Mehrotra, MD, D.Phil. ${ }^{a}$, Sukh Mahendra Singh, Ph.D. ${ }^{c}$, Alok Chandra Bharti, Ph.D. ${ }^{\mathrm{a}, \mathrm{b}^{*}}$

aDivision of Molecular Oncology, ICMR- National Institute of Cancer Prevention and Research, Noida, Uttar Pradesh, India; ' Molecular Oncology Laboratory, Department of Zoology, University of Delhi, New Delhi; 'School of Biotechnology, Banaras Hindu University, Varanasi, Uttar Pradesh; 'Subharti Dental College, Meerut, Uttar Pradesh;

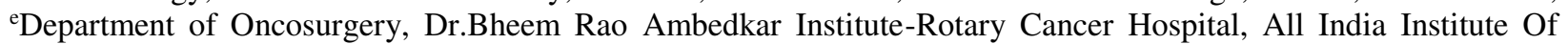

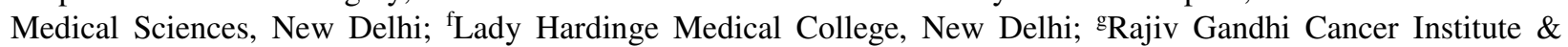
Research Centre, New Delhi.

*Address for Correspondence and Re-prints:

14 Prof. Alok C. Bharti, Molecular Oncology Laboratory, Department of Zoology, University of Delhi, Delhi, 110007, India. Mobile: +91-8800171246, Email: alokchandrab@yahoo.com

\# Present address

Manuscript Statistics - Abstract - 199 words, Manuscript - 4345 words, Manuscript pages - 20 References - 70, 
24 GV- Participated in study design, performed major experimental work and manuscript preparation; NA- helped in 25 final preparation of manuscript, communication and revision; AT- assisted in experimental work and data analysis; $26 \mathrm{KV}, \mathrm{MJ}$ and TS- helped in experimental work and manuscript preparation; AG, DP, AS, KA, US and DCD-

27 participated in enrollment of study subjects, their clinical evaluation, provided staging, histopathological grading, 28 tumor diagnosis and specimen collection; SS- participated in statistical evaluation of data; RM, SMS- performed 29 evaluation of clinical and experimental data, assisted in critical review of the manuscript; ACB- conceived and 30 designed the study, evaluated data, and critically reviewed, drafted and communicated the final manuscript. All authors 31 have read and approved the final manuscript.

\section{Funding Information}

33 The study was supported by research grants from Department of Biotechnology (DBT:624234 P34/RGCB/PMD/DBT/ALCB/2015) and Indian Council of Medical Research (ICMR:HIV/50/139/20101-ECDII), 35 Government of India to ACB, UGC-Junior Research Fellowship to GV and KV [F.2-2/2009 (SA-I)], Grant from 36 ICMR to AT (81/3/2009/BMS/Stem Cell) and MJ (3/2/2/278/2014/NCDIII), UGC-Junior Research Fellowship to TS 37 (2061430699 22/06/2014 (i)EU-V), Grant from CSIR to NA (17/12/2017(ii) EU-V)

Conflicts of Interest: The authors declare that there are no conflicts of interests.

39 Availability of data and material: The datasets generated during and/or analysed during the current study are 40 available from the corresponding author on reasonable request.

41 Code availability: Not applicable

42 Ethics approval: Not applicable 
44 - Xylene-free pre-treatment of FFPE tissues improved DNA quality and HPV detection.

45 - FFPE specimen showed HPV positivity of $23.4 \%$ using short amplicon GP5+/GP6+ PCR.

46 - HPV detection from FFPE specimen showed concordance with fresh tissues.

47 - Oral cancers reported at dental hospital facility showed HPV18 positivity.

48 - Cancer hospitals samples matched HPV positivity, differed in oral sub-sites reported.

49

50

51

52

53

54

55

56

57

58

59

60

61

62

63

64

65

66

67

68

69

70 


\section{Abstract}

72 Incidence of human papillomavirus (HPV)-associated oral cancers is on the rise. However, epidemiological data of

73 this subset of cancers is limited. Dental hospital pose a unique advantage in detection of HPV-positive oral

74 malignancies. We assessed the utility of formalin-fixed, paraffin-embedded (FFPE) tissues, which are readily

75 available, for evaluation of high-risk HPV infection in oral cancer. For protocol standardization, we used 20

76 prospectively-collected, paired FFPE and fresh tissues of histopathologically-confirmed oral cancer cases reported in

77 Oral Medicine department of a dental hospital for comparative study. Only short-PCRs ( 200bp) of DNA isolated

78 using a modified xylene-free method displayed a concordant HPV result. For HPV analysis, we used additional 30

79 retrospectively-collected FFPE tissues. DNA isolated from these specimens showed an overall 23.4\% (11/47) HPV

80 positivity with detection of HPV18. Comparison of HPV positivity from dental hospital FFPE-specimens with overall

81 HPV positivity of freshly-collected oral cancer specimens (n-55) from three cancer care hospitals of the same region

82 showed notable difference (12.7\%; 7/55). Further, cancer hospital specimens showed HPV16 positivity and displayed

83 a characteristic difference in reported sub-sites and patient spectrum. Overall, using a xylene-free FFPE-DNA isolation

84 method clubbed with short amplicon PCR, we showed detection of HPV-positive oral cancer in dental hospitals.

85 Keywords: Oral cancer, human papillomavirus, formalin-fixed paraffin-embedded, xylene-free DNA isolation, dental 86 hospital. 


\section{Introduction}

India harbors the world's largest number of oral cancer cases (Bray et al., 2018; Dikshit et al., 2012). Oral cancers are among the largest group of preventable cancers. Regular screening and prevention of high-risk habits like smoking, tobacco chewing, consumption of alcohol and areca nut could effectively control them (Brennan et al., 1995). These cancers are biologically and psychologically the worst when diagnosed at an advanced stage. Oral cancer is currently on the rise, particularly in specific geographic regions like India (Dikshit et al., 2012).

Lately, based on the status of Human Papillomavirus (HPV) infection, oral cancer has been classified as molecularly and clinically distinct subset (Gillison et al., 2000). Infection of high risk-HPVs is becoming a significant contributor, a decisive risk factor, and likely an etiological agent for these subsets of oral cancers (Aggarwal et al., 2020; Gillison et al., 2014; Syrjanen, Rautava, and Syrjanen, 2017). These cancers occur early in age and have no prior history of tobacco and/or high alcohol consumption (Gillison et al., 2000). Comparatively, HPV-positive oral cancers are at lower risk of tumor progression and related mortality with improved chemotherapy/radiotherapy response (Lesnikova et al., 2010; Ragin and Taioli, 2007; Weinberger et al., 2006; Westra, 2014). The incidence trend, particularly in the USA demonstrates an increase in reporting of new HPV-related oral cancer (Marur et al., 2010; Sturgis and Cinciripini, 2007). Whereas, HPV-unrelated oral cancer are reported as stable or on decline, which is consistent with gradual reductions in tobacco use (Chaturvedi et al., 2013). Among different HPV's in the oral cavity, HPV16 and HPV18 are the commonly detected genotypes (Chaturvedi et al., 2008; Machado et al., 2010). More than 90\% of HPV-positive oral cancer are infected predominantly with the HPV16 genotype (Castellsague et al., 2016; Castro et al., 2015; Mishra et al., 2006; Westra, 2014), whereas the presence of HPV18 has been reported only sporadically in a few specific studies (Baay et al., 1996; Balaram et al., 1995; Chang, Lin, and Chiang, 2003; Dhanapal et al., 2015; Gan et al., 2014; Lesnikova et al., 2010).

Unlike cervical cancer, an established clinical infrastructure for screening of oral cancer or clear clinical guidelines for testing of HPV infection in oral lesions do not exist. Further, there is no validated screening methods for oral cancer. Thus, the field is still in its relative infancy. However, a clear advantage of oral screening for mucosal abnormalities was demonstrated in a randomized trial conducted in India that showed a reduction in oral cancer mortality rates (Sankaranarayanan et al., 2005). Therefore, understanding the status of HPV infection in a suspected lesion at an early stage will be extremely helpful in management and control of oral cancer. Majority of oral lesions 
114 with or without dental involvements usually encountered first at oral medicine/ oral surgery clinics of the dental 115 hospital. Therefore, dental hospitals can serve as primary opportunistic screening sites (Lim et al., 2003; McGurk and 116 Scott, 2010) and may cater to prevention and early management of oral cancer.

Formalin-fixed paraffin-embedded (FFPE) tissues represent a potentially useful and readily available resource for HPV detection in oral cancer (Cannavo et al., 2012). Several HPV studies have used FFPE specimens in the past to correlate HPV genotypes with histological classification in oral cancer (Balaram et al., 1995; Hatakeyama et al., 2014; Mishra et al., 2006) and other cancers (Odida et al., 2010). Though HPV detection is feasible in DNA

121 isolated from FFPE, it poses several technical challenges for subsequent PCR-based diagnostics (Kocjan, Hosnjak, 122 and Poljak, 2015). Moreover, there has been no study, which measured the concordance of HPV positivity detected in FFPE tissues with paired fresh oral cancer biopsies. hospital and evaluated the FFPE tissues from prospectively collected, histopathologically-confirmed oral cancer cases along with the paired fresh biopsies. Fresh biopsy DNA served as a reference for assessing the quality of FFPE DNA

127 for adequacy test and subsequent HPV diagnosis. To achieve better results, we modified the xylene-free DNA extraction protocol. Further, we validated the technique by evaluating HPV positivity in FFPE specimen of retrospective oral cancer cases reported in the dental hospital. Additionally, we compared the HPV positivity in FFPE tissues from dental hospital with the HPV positivity routinely observed in freshly collected oral cancer from three cancer hospitals of same region to highlight similarities/differences in HPV spectrum in two different hospital settings.

\section{Subjects and Methods}

2.1. Clinical specimens and the study design: The comparative study was performed on 146 oral or oropharyngeal cancer cases from a dental and 3 tertiary cancer care hospitals (TCCH) (Table 1). All the samples that were available during the study period, were collected before any chemo/radiotherapy from four centers, namely: Department of Medical Oncology, Rajiv Gandhi Cancer Institute \& Research Centre (RGCI), New Delhi; Department of Surgical Oncology, All India Institute of Medical Sciences (AIIMS), New Delhi; Department of Medicine, Lady Harding Medical College (LHMC), New Delhi and Subharti Dental College and Hospital (SDCH), Meerut during October 2009 till November 2015. Centre-wise sample distribution and their subsequent processing for HPV detection are described in Fig. 1. Prior written informed consent was obtained from all the subjects included in the study according 
141 to the principle laid down by the declaration of Helsinki, and epidemiological details were taken from their clinical

142 records. For retrospective analysis, archival tissue blocks of histopathologically-confirmed oral cancer cases reported

143 at Subharti Dental Hospital were used. The study protocol was approved by the Institutional Ethics Committee of all

144 collaborating hospitals and from the National Institute of Cancer Prevention and Research (NICPR: earlier named as

145 Institute of Cytology \& Preventive Oncology), Noida, India, where the laboratory work was carried out. A portion of

146 each biopsy collected in cold $1 \mathrm{X}$ phosphate buffer saline (PBS) was immediately processed for molecular biological

147 analysis or stored at $-80^{\circ} \mathrm{C}$ until further used, and the other half was sent for histopathological diagnosis in formalin

148 solution as a routine strategy. In the case of DNA isolation and HPV detection in paired FFPE tissues, sections were

149 retrieved after histopathological evaluation and confirmation of oral malignancy.

150

151

152

153

154

155

2.2. Materials: Important reagents used in the study are Taq polymerase (AmpliTaq Gold® 360 DNA Polymerase, ABI 4398896), PCRII 10X buffer (included with AmpliTaq Gold®), $25 \mathrm{mM} \mathrm{MgCl}$ (included with AmpliTaq Gold®), dNTPs (100 mM each, Applied Biosystems), Taq Buffer (Bangalore Genei, Merck METB1S), Taq DNA Polymerase

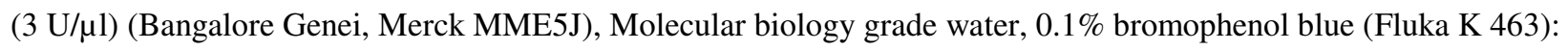
dissolve $0.25 \mathrm{~g}$ bromophenol blue in $50 \mathrm{~mL}, 70 \%$ ethanol (made from Merck 1.00983) and Tween-20 (Sigma, P9416100ML). DNA derived from HPV-negative cancer cell line C33a was used as negative control. International standards for HPV16/18 procured from NIBSC (London) under WHO HPV Lab-Net programme were used as reference DNA and positive controls for HPV detection protocols. All other reagents used in the study were of analytical and molecular biology grade and were procured from Sigma Aldrich (USA) unless specified. Custom-synthesized, HPLC-purified primers were procured from M/s Microsynth (Germany) or M/s Eurogentec (Belgium). List of primer used in the present study are described in Table 2.

2.3. Genomic DNA Isolation from oral cancer fresh biopsies and FFPE samples: Genomic DNA was isolated from freshly-collected oral cancer biopsies by the proteinase $\mathrm{K}$ digestion followed by phenol-chloroform extraction procedure described earlier (Shukla et al., 2010a) and referred as protocol P1 (Table 3). PCR amplification was performed following the reference protocol P1. Genomic DNA extraction from FFPE scrape specimens (5 sections of $5 \mu \mathrm{m}$ thickness) was performed by two different protocols for comparative analysis. First deparaffinization was done by xylene-based method as described earlier (Coombs, Gough, and Primrose, 1999) and referred as protocol P2 (Table 3). Briefly, sections were left in xylene for $5 \mathrm{~min}$. or repeated if any paraffin remains and rehydrated using graded alcohol series. Alternatively, paraffin was removed by xylene-free method with slight modification and referred as 


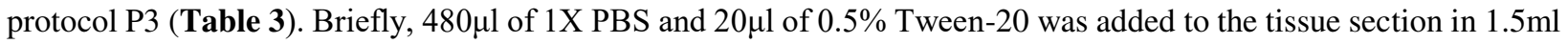
tube and incubated for $10 \mathrm{~min}$. at $90^{\circ} \mathrm{C}$ in pre-equilibrated heating block. After incubation, the tissue was centrifuged

171 at $10,000 \mathrm{~g}$ for $15 \mathrm{~min}$. at room temperature and later kept on ice for $2 \mathrm{~min}$. The resulting tissue pellet was obtained by 172 removing the wax disc and the supernatant. The tissue pellet was then dissolved in $500 \mu$ of $1 \%$ Tissue Lysis Buffer $173(0.5 \mathrm{M}$ EDTA, $20 \mathrm{mg} / \mathrm{ml}$ proteinase $\mathrm{K}, 100 \mathrm{mM}$ Tris-Cl, $\mathrm{pH}-8,10 \%$ SDS $)$ and further incubated overnight at $60^{\circ} \mathrm{C}$ in 174 pre-calibrated water bath for digestion. The digested suspension was used for DNA extraction by routine phenol175 chloroform method. The DNA pellet was collected by centrifugation for $5 \mathrm{~min}$. at $4{ }^{\circ} \mathrm{C}$, washed with $100 \%$ ethanol, air dried at room temperature or in speed vac and re-suspended in $50 \mu \mathrm{l}$ of double distilled water, and kept at $-20^{\circ} \mathrm{C}$ until use. The quality and quantity of isolated genomic DNA from oral cancer biopsies and FFPE tissue sections was assessed by electrophoresis on 1\% agarose gel with ethidium bromide in 1X TAE buffer.

2.4. Prevention of cross-contamination: Strict attention was observed while sectioning and subsequent processing. Paraffin sections were prepared according to the sandwich method: the first and last sections were stained by haematoxylin and eosin to check for tumor presence and to guide microdissection. The tumor specimens were divided into two parts. One part was fixed in $10 \%$ formalin and examined at Department of Pathology for histopathological evaluation, while the other part was stored at $-80^{\circ} \mathrm{C}$ until transferred to the Molecular Oncology Laboratory at NICPR for analysis. From each tissue block, ten 5- $\mu$ m thick sections were cut and placed in two 1.5 -mL microcentrifuge tubes for DNA extraction and HPV analysis. After each block, the microtome sectioning area was cleaned with acetone and $70 \%$ ethanol. To avoid cross-contamination, each tissue block was handled with new gloves and fresh microtome blade was used each time a new block was sectioned, disposable filter tips were used for all pipetting steps and separate zones were used for pre- and post-PCR handling. Extraction buffer aliquots without tissue samples were used as negative controls during DNA isolations (one buffer control per 10 samples). Water samples (one per 10 tissues) and PCR master mix without template (one per 10 tissues) were included to monitor reagents contamination and potential cross-contamination in PCR experiments. cancer by PCR using consensus degenerate sequence-specific primers PGMY09/PGMY11 and GP5+/GP6+ and its 194 typing the adequacy of DNA was assessed by subjecting the genomic DNA (100ng/reaction) isolated from above195 mentioned methods for $\beta$-globin or p53 Exon 5 PCR which were used as internal controls targeted to host genomic DNA. The PCR products were checked using $2 \%$ agarose gels stained with Ethidium Bromide and compared with 
HaeIII digested $\Phi$ x174 DNA as molecular weight marker. All negative samples with adequate DNA on agarose were subjected to re-extraction to remove potential PCR inhibitors and rechecked by PCR for internal control.

2.6. HPV Detection and Typing: PCR was carried out to amplify L1 region of about $33 \mathrm{HPV}$ types that included all high-risk HPVs using consensus PGMY09/11 and GP5+/GP6+ primers that target L1 region but of different sizes. After amplification, the products were analyzed on $2 \%$ agarose gel electrophoresis. Similarly all samples were further processed for HPV genotyping by HPV type-specific PCR for HPV16 and HPV18 with short amplicon sizes as described previously (Shukla et al., 2010b). The PCR procedures were as follows: initial denaturation and hot-start activation at $95^{\circ} \mathrm{C}$ for $10 \mathrm{~min}$. followed by 35 cycles of $95^{\circ} \mathrm{C}$ for $30 \mathrm{~s}, 55^{\circ} \mathrm{C}$ for $30 \mathrm{~s}$ and $72^{\circ} \mathrm{C}$ for 30 s for every $\mathrm{PCR}$ except annealing of p53 (exon5) was carried out at $61^{\circ} \mathrm{C}$. Each PCR was performed with negative (genomic DNA of HPV-negative C33a cells and $\mathrm{ddH}_{2} \mathrm{O}$ as blank) and positive controls (pre-calibrated plasmid DNA from WHOinternational standards for HPV16/18). The overall sensitivity of PCR for HPV16 and HPV18 was 50copies/5 1 DNA (100 ng human genomic DNA).

2.7. Statistical analysis: Statistical analysis for HPV percent positivity with respect to different variables and hospital type was performed by the chi-square test for proportion using Epi Info 6 version 6.04d PLUS statistical software. Chi-square and Fisher's exact test was employed as and when required to find an association between the results obtained from both the centers with respect to staging, grading, site, and sub-site using IBM SPSS statistics software version 2015. For all analyses, $p \leq 0.05$ considered significant. Concordance between the techniques was observed by calculating the agreement and their respective Cohen-kappa value (к) by online available Kappa-value calculator website EasyCalculation.com.

\section{Results}

\subsection{Isolation of Genomic DNA from FFPE specimens from oral cancer and their performance in HPV PCRs:} Efficiency of DNA isolated from FFPE tissues and its suitability for subsequent HPV PCRs was tested. Evaluation of DNA isolated from FFPE tissues in comparison to the DNA isolated from freshly collected paired biopsies using reference protocol showed the presence of detectable genomic DNA only in xylene-free method (Fig. 3 left panels). In contrast, no DNA could be detected in the xylene-based method (data not shown). To ascertain the quality of DNA

222 isolated from FFPE in PCR-based assays, this DNA were subjected to amplification of genomic fragments of $\beta$-globin 223 (268bp in size) and p53 (184bp in size), which revealed amplification of only 184bp fragment in FFPE samples (Fig. 

primers showed amplifications in all the DNA samples of xylene-free method, whereas only $20 \%(4 / 20)$ specimens showed amplification in DNA isolated from xylene-based pre-treatment method. HPV PCRs targeted to L1 region using primers targeted to long (PGMY9/11; 450bp) and short (GP5+/GP6+; 127bp) region of HPV genome demonstrated efficient amplification of short fragment PCR in oral cancer DNA isolated from biopsies or xylene-free protocol, but completely failed in xylene-based protocol (Fig. 4) (Table 3). The HPV detection using GP5+/GP6+ primers in FFPE DNA isolated from xylene-free protocol was concordant with reference results from fresh biopsies. Similarly, HPV18 PCR that amplified 100bp fragment of HPV18 E6 was positive in 2 cases and corresponded well with results obtained using reference protocol (Fig. 5). Incidentally, all oral cancer DNA, irrespective of whether derived from FFPE or fresh tissue biopsies did not show any HPV16 amplification (Table 3).

3.2. Generic and type-specific prevalence of HPV infection in oral cancer using FFPE tissues: Overall, HPV positivity in the regional dental hospital was evaluated by incorporating the study of retrospective FFPE samples of 30 additional oral cancer cases reported in the dental hospital from which the DNA was isolated with xylene-free protocol. Among these, 3 samples failed on internal control PCR yielding cumulative sample adequacy of 94\% (Table 4). Overall, $11 \%$ (5/47) samples were positive for PGMY9/11, whereas $23.4 \%$ (11/47) samples were positive for GP5+/GP6+ PCR in oral cancer cases reported at the regional dental hospital. Among these HPV positive samples, 5 samples were found HPV18-positive, but none showed HPV16 positivity.

To validate this unexpected HPV18 positivity, HPV prevalence and type-specific presence of HPV16 and HPV18 was examined in prospectively-collected fresh oral/oropharyngeal biopsies from cases reported at three TCCH of the region which revealed an overall HPV positivity of 10.2\% (9/88) and 22\% (20/88) by PGMY09/11 and GP5+/GP6+ primers, respectively. All PGMY09/11 positive cases were also positive for GP5+/GP6+. Therefore, for all subsequent analysis, only PCR results from GP5+/GP6+, which also performed efficiently in FFPE tissue, were taken into consideration for further analysis. Among 3 cancer hospitals, the HPV positivity varied considerably from 0\% (AIIMS) to 35.7\% in (LHMC) when we compared it with the oral cancer cases reported at dental hospital irrespective of the primers used for generic HPV detection. Higher incidence of HPV infection was detected by GP5+/GP6+ PCR (23.4\% in dental and 22.7\% in cancer hospital compared to $11 \%$ and $10.2 \%$ in PGMY9/11 PCR respectively concordance $87.5 \%$ and $\kappa$-value $=0.558$ ). Interestingly, $53 \%$ of the oral cancer cases reported as HPVpositive were harboring HPV16, whereas no HPV18 infection was detectable in any of the cancer hospital samples. 

and cancer hospitals: Clinico-pathological and demographic evaluation of HPV-negative and HPV-positive oral cancer cases revealed a distinct spectrum of patients in dental hospital (Table 5). Lower age group of oral cancer cases reported at the dental hospital (mean age 46.6yr vs 53.6yr (oral cancer cases only) vs 54.6yr (oral and oropharyngeal cancer cases); $p<0.001)$. The mean age of the HPV-positive case was relatively lower than the HPV-negative case (39.6 $\pm 15.0 \mathrm{yr}$ vs $48.8 \pm 14.0 \mathrm{yr}) p=0.06$. Proportionately more women reported this malignancy at dental hospitals, and with a higher percentage of them were found as HPV-positive. Evaluation of oral cancer sample distribution with respective oral sub-sites demonstrated cancers of the oropharyngeal region were not reported in dental hospitals, whereas the frequency of tongue cancers reported in dental hospitals was low. Nevertheless, the overall HPV positivity in the dental hospital when compared with all cancers of the oral cavity reported at cancer hospital (that include the case of oropharyngeal cancer also) was very similar in both settings. However, further segregation and comparison with only oral cancer cases of dental and cancer hospitals showed a considerably higher frequency of HPV positivity at the dental hospital $(23.0 \%$ vs. $12.7 \% ; p=0.01)$. Overall, reporting of alveolar gingival oral cancer was similar at two centers, but the HPV positivity on this site varied. Alveolar gingival oral cancer of the dental hospital showed higher HPV positivity ( $26.6 \%$ in dental vs. $16.6 \%$ in cancer hospital; $p=0.015$ ). It is also to note that none of these tissues were HPV16 positive even in cases reported in cancer hospitals. On the other hand, tongue cancer that was reported at a higher proportion in cancer hospitals showed variable HPV positivity; tongue oral cancer cases were reported at frequencies that could not be analyzed due to the small number of cases (1/4 in dental; $1 / 14$ in cancer hospital) in both hospital settings with similar HPV positivity.

272 cancer cases reported at cancer or dental hospital even if they were clubbed together. Oropharyngeal cancer $39.4 \%$ vs 273 oral cancer dental $23.0 \%$ vs oral cancer hospitals $12.7 \%$ vs $(17.8 \% ; p=<0.05)$. A comparison of oral cancer presented 274 with different histopathological grades in two setting demonstrated a higher proportion of cases of Well Differentiated 275 Squamous Cell (WDSCC) type (72.3\% in dental vs. 54.0\% in cancer hospital). Further, these WDSCC cases reported 276 in dental hospitals displayed a higher HPV positivity (20.6\% vs. 6.7\% in WDSCC of cancer hospital; $p$ - 0.014 ). 277 Evaluation of clinical stage-wise comparison distribution of cases between dental and cancer hospitals as well as their 278 HPV positivity, did not show any statistically significant difference. 
To our knowledge, this is the first study that compared HPV prevalence in oral cancer at two different clinical settings viz a viz dental and cancer care hospitals. In addition, we explored the option of FFPE-based evaluation of oral lesions for HPV detection. We report efficient isolation of DNA from FFPE specimens using a modified xylenefree approach and found the conditional suitability of the DNA isolated for subsequent PCR-based HPV detection assays. The study also compared the spectrum of oral cancer malignancies and their HPV positivity in these two settings. We found a higher HPV positivity in oral cancer cases reported at the dental hospital as compared to the TCCH of the same region. Genotyping of the infection revealed the presence of HPV type 18 in FFPE samples from dental facility in contrast to detection of HPV16 in fresh biopsies from TCCH.

Detection of HPV infection using DNA isolated from FFPE samples is a challenging approach. DNA from FFPE tissues are usually extracted in fragmented form (Baay et al., 1996; Karlsen et al., 1994). A series of investigations have been performed using the FFPE-specimens with variable HPV positivity ranging upto 74\% (Table 6). Some of the investigators attempted to compare the results obtained from FFPE with freshly-collected casematched biopsies (Palmer et al., 2014). However, they used non-malignant tonsillar tissue where they did not find any HPV positivity. In the present study, we evaluated FFPE tissues and their paired fresh biopsies for analysis of concordance and observed that DNA isolated shows fully concordant results only when the xylene-free method is used in combination with PCRs that amplify short targets. A similar direct approach on oral FFPE tissues was applied in some other studies which claimed over $90 \%$ adequacy (Fig. 2; Table 6), but we could not get any amplifiable DNA using this approach (data not shown). Among other few approaches for pretreatment of FFPE sections, the xylenebased method of wax removal was most preferred (Fig. 2) which was also found associated with compromised sample adequacy for PCR-based detection in our study and by others (Resnick et al., 1990).

On the other hand, choice of assay selection for downstream HPV PCR amplification was entirely based on availability of validated short amplicon consensus and type-specific PCR primers in our laboratory. There are a number of assays, which employ shorter fragment lengths for HPV detection, which arguably could be more sensitive than the primers used in the present study (Table 6). Notably, the high concordance rate observed in our study was feasible only in PCRs that targeted shorter fragments of DNA for amplification. These results show that DNA fragment length is an essential factor in the evaluation of DNA isolated from FFPE specimen. While using FFPE samples, best PCR amplification with primers amplifying short bp amplicons ( 200bp) has been proposed (Cannavo et al., 2012). Difficulties with PCR amplification >200-300bp were reported (Bonin and Stanta, 2013; Kocjan et al., 2015). An 
antagonistic effect of formaldehyde fixation due to DNA modification and crosslinking has also been implicated in the inhibition of PCR amplification of longer (>200-bp) amplicons (Karlsen et al., 1994), and efficiency of the primer pair have been proposed to correlate inversely with the length of the amplicons (Baay et al., 1996).

The overall analysis of HPV prevalence in oral cancer using FFPE specimens from the dental hospital showed positivity of $23.4 \%$ by GP5+/GP6+ PCR. Our previous investigations for the detection of HPV positivity in freshlycollected biopsies of oral cancer from the same geographical region demonstrated a similar prevalence (Gupta et al., 2015; Mishra et al., 2006). HPV prevalence reported in oral cancer across different regions of India suggests regionspecific variation apart from technical differences in HPV positivity (Fig. 6; Supplementary ST1). However, there was a sharp contrast in the results when we examined the presence of HPV types 16 and 18. Our earlier reports generated on samples collected from cancer care hospitals however always indicated the presence of HPV16 as the dominant HPV type seen in oral cancer. Interestingly, a recent study performed on 23 archival tissues of oral cancers from dental hospital settings from the same region has reported the presence of HPV18 with a comparable frequency (Dhanapal et al., 2015). Reasons behind such discrepant observations are not known, but observations with such discordant HPV results have been reported by other investigators (Odida et al., 2008). Loss of HPV16 and a few other genomes due to formalin-fixation that resulted in a reduction in their sensitivity of PCR detection cannot be ruled out.

Nevertheless, finding only HPV18 in oral cancer from the dental hospital was unusual and required further investigation. A pooled analysis of specimens from the three centers revealed HPV positivity that closely resembled to the one observed in FFPE tissues from dental hospital. The reported prevalence of HPV16 in oral cancer ranges from 58\% to 66\% (Kreimer et al., 2005; Shi et al., 2009), whereas HPV18 is the second most common type of HPV detected in oral cancer. It is found at much less frequently in HPV-positive oropharyngeal SCCs (2.9\%) compared with HPV-positive oral SCCs (34.5\%) or HPV-positive laryngeal SCCs (17.2\%) (Kreimer et al., 2005; Shi et al., 2009). Disproportionately high HPV18 prevalence have been reported from Indian or other geographical regions (Balaram et al., 1995; Boy et al., 2006; Dhanapal et al., 2015; Gan et al., 2014; Kreimer et al., 2005; Kulkarni et al., 2011).

The spectrum of oral cancer cases presented at dental hospital differed significantly with respect to sub-sites. This hospital setting completely lacked reporting of oropharyngeal cancers, lesser number of tongue cancers, higher proportion of cancers in women, cases with lower mean age, and over representation of tumor tissues with WDSCC 
histopathology. The most apparent reason for the skewed spectrum of oral cancers could be their association with reporting malignancies that likely had dental involvement. These cancer cases displayed a higher HPV positivity in

337 general when compared to similar cases of oral sub-sites were compared from cancer hospitals. HPV18 positivity was

338 found associated with alveolar/gingival, buccal mucosa, and retro-molar space. HPV18 has a special tropism for 339 glandular tissue and is the most frequently detected type in adenocarcinomas of the cervix. Adenocarcinomas are rare 340 in the head and neck (Kreimer et al., 2005) and occur mainly in salivary gland tumors (Quintero et al., 2013). Further, 341 a higher HPV positivity was detected in oral cancer cases of the dental hospital that were having well-differentiated 342 histopathology. The reasons for such observations are not known. In general, HPV positivity has been associated with 343 differentiated lesions (Fakhry and Gillison, 2006; Mishra et al., 2006; Syrjanen et al., 2011), but the reason(s) for the 344 observed over-representation only in dental hospital cases is not known.

Taken together, our study show the utility of FFPE samples for detection of HPV infection in the malignant oral lesion and can be clubbed with their routine histopathological evaluation. Our study's outcome also suggests 347 potential over-representation of HPV-positive oral cancers with HPV18 positivity in malignancies reported in dental 348 hospital as opposed to the frank locally-advanced malignancies reported in TCCH that conventionally report a high 349 incidence of HPV16 - positive oral cancer. Moreover, dental hospitals may play a pivotal role in the de-intensification of subsequent treatment of HPV-positive oral lesions right from the beginning if they report the HPV status along with the histopathological findings. 


\section{Bibliography}

1. Aggarwal, N., Yadav, J., Thakur, K., Bibban, R., Chhokar, A., Tripathi, T., Bhat, A., Singh, T., Jadli, M., Singh, U., Kashyap, M.K. and Bharti, A.C., 2020. Human papillomavirus infection in head and neck carcinomas: Transcriptional triggers and changed disease patterns. Frontiers Cellular and Infection Microbiology (In press).

2. Baay, M.F., Quint, W.G., Koudstaal, J., Hollema, H., Duk, J.M., Burger, M.P., Stolz, E. and Herbrink, P., 1996. Comprehensive study of several general and type-specific primer pairs for detection of human papillomavirus DNA by PCR in paraffin-embedded cervical carcinomas. Journal of clinical microbiology 34, 745-7.

3. Balaram, P., Nalinakumari, K.R., Abraham, E., Balan, A., Hareendran, N.K., Bernard, H.U. and Chan, S.Y., 1995. Human papillomaviruses in 91 oral cancers from Indian betel quid chewers-high prevalence and multiplicity of infections. Int J Cancer 61, 450-4.

4. Bandhary, S.K., Shetty, V., Saldanha, M., Gatti, P., Devegowda, D., R, P.S. and Shetty, A.K., 2018. Detection of Human Papilloma Virus and Risk Factors among Patients with Head and Neck Squamous Cell Carcinoma Attending a Tertiary Referral Centre in South India. Asian Pacific journal of cancer prevention : APJCP 19, 1325-1330.

5. Bonin, S. and Stanta, G., 2013. Nucleic acid extraction methods from fixed and paraffinembedded tissues in cancer diagnostics. Expert review of molecular diagnostics 13, 271-82.

6. Boy, S., Van Rensburg, E.J., Engelbrecht, S., Dreyer, L., van Heerden, M. and van Heerden, W., 2006. HPV detection in primary intra-oral squamous cell carcinomas--commensal, aetiological agent or contamination? Journal of oral pathology \& medicine : official publication of the International Association of Oral Pathologists and the American Academy of Oral Pathology 35, 86-90.

7. Bray, F., Ferlay, J., Soerjomataram, I., Siegel, R.L., Torre, L.A. and Jemal, A., 2018. Global cancer statistics 2018: GLOBOCAN estimates of incidence and mortality worldwide for 36 cancers in 185 countries. CA: a cancer journal for clinicians $68,394-424$.

8. Brennan, J.A., Boyle, J.O., Koch, W.M., Goodman, S.N., Hruban, R.H., Eby, Y.J., Couch, M.J., Forastiere, A.A. and Sidransky, D., 1995. Association between cigarette smoking and mutation of the p53 gene in squamous-cell carcinoma of the head and neck. N Engl J Med 332, 712-7.

9. Cai, L., Yu, S.Z. and Zhang, Z.F., 2001. Glutathione S-transferases M1, T1 genotypes and the risk of gastric cancer: a case-control study. World journal of gastroenterology 7, 506-9.

10. Cannavo, I., Loubatier, C., Chevallier, A. and Giordanengo, V., 2012. Improvement of DNA extraction for human papillomavirus genotyping from formalin-fixed paraffin-embedded tissues. BioResearch open access 1, 333-7.

11. Castellsague, X., Alemany, L., Quer, M., Halec, G., Quiros, B., Tous, S., Clavero, O., Alos, L., Biegner, T., Szafarowski, T., Alejo, M., Holzinger, D., Cadena, E., Claros, E., Hall, G., Laco, J., Poljak, M., Benevolo, M., Kasamatsu, E., Mehanna, H., Ndiaye, C., Guimera, N., Lloveras, B., Leon, X., Ruiz-Cabezas, J.C., Alvarado-Cabrero, I., Kang, C.S., Oh, J.K., Garcia-Rojo, M., Iljazovic, E., Ajayi, O.F., Duarte, F., Nessa, A., Tinoco, L., Duran-Padilla, M.A., Pirog, E.C., Viarheichyk, H., Morales, H., Costes, V., Felix, A., Germar, M.J., Mena, M., Ruacan, A., Jain, A., Mehrotra, R., Goodman, M.T., Lombardi, L.E., Ferrera, A., Malami, S., Albanesi, E.I., Dabed, P., Molina, C., Lopez-Revilla, R., Mandys, V., Gonzalez, M.E., Velasco, J., Bravo, I.G., Quint, W., Pawlita, M., Munoz, N., Sanjose, S. and Xavier Bosch, F., 2016. HPV Involvement in Head and Neck Cancers: Comprehensive Assessment of Biomarkers in 3680 Patients. Journal of the National Cancer Institute 108.

12. Castro, F.A., Koshiol, J., Quint, W., Wheeler, C.M., Gillison, M.L., Vaughan, L.M., Kleter, B., van Doorn, L.J., Chaturvedi, A.K., Hildesheim, A., Schiffman, M., Wang, S.S., Zuna, R.E., Walker, J.L., Dunn, S.T. and Wentzensen, N., 2015. Detection of HPV DNA in paraffinembedded cervical samples: a comparison of four genotyping methods. BMC infectious diseases 15,544 . 
13. Chang, J.Y., Lin, M.C. and Chiang, C.P., 2003. High-risk human papillomaviruses may have an important role in non-oral habits-associated oral squamous cell carcinomas in Taiwan. American journal of clinical pathology 120, 909-16.

14. Chaturvedi, A.K., Anderson, W.F., Lortet-Tieulent, J., Curado, M.P., Ferlay, J., Franceschi, S., Rosenberg, P.S., Bray, F. and Gillison, M.L., 2013. Worldwide trends in incidence rates for oral cavity and oropharyngeal cancers. J Clin Oncol 31, 4550-9.

15. Chaturvedi, A.K., Engels, E.A., Anderson, W.F. and Gillison, M.L., 2008. Incidence trends for human papillomavirus-related and -unrelated oral squamous cell carcinomas in the United States. J Clin Oncol 26, 612-9.

16. Chaudhary, A.K., Pandya, S., Mehrotra, R., Bharti, A.C., Singh, M. and Singh, M., 2010. Comparative study between the Hybrid Capture II test and PCR based assay for the detection of human papillomavirus DNA in oral submucous fibrosis and oral squamous cell carcinoma. Virology journal 7, 253.

17. Coombs, N.J., Gough, A.C. and Primrose, J.N., 1999. Optimisation of DNA and RNA extraction from archival formalin-fixed tissue. Nucleic acids research 27, e12.

18. D'Costa, J., Saranath, D., Dedhia, P., Sanghvi, V. and Mehta, A.R., 1998. Detection of HPV-16 genome in human oral cancers and potentially malignant lesions from India. Oral oncology 34, 413-20.

19. Dhanapal, R., Ranganathan, K., Kondaiah, P., Devi, R.U., Joshua, E. and Saraswathi, T.R., 2015. High-risk human papilloma virus in archival tissues of oral pathosis and normal oral mucosa. Contemporary clinical dentistry 6, 148-52.

20. Dikshit, R., Gupta, P.C., Ramasundarahettige, C., Gajalakshmi, V., Aleksandrowicz, L., Badwe, R., Kumar, R., Roy, S., Suraweera, W., Bray, F., Mallath, M., Singh, P.K., Sinha, D.N., Shet, A.S., Gelband, H. and Jha, P., 2012. Cancer mortality in India: a nationally representative survey. Lancet 379, 1807-16.

21. Erhart, S.M., Rivero, E.R., Bazzo, M.L. and Onofre, A.S., 2015. Comparative evaluation of the GP5+/6+, MY09/11 and PGMY09/11 primer sets for HPV detection by PCR in oral squamous cell carcinomas. Experimental and molecular pathology 100, 13-16.

22. Fakhry, C. and Gillison, M.L., 2006. Clinical implications of human papillomavirus in head and neck cancers. J Clin Oncol 24, 2606-11.

23. Gan, L.L., Zhang, H., Guo, J.H. and Fan, M.W., 2014. Prevalence of human papillomavirus infection in oral squamous cell carcinoma: a case-control study in Wuhan, China. Asian Pacific journal of cancer prevention : APJCP 15, 5861-5.

24. Ghosh, A., Ghosh, S., Maiti, G.P., Sabbir, M.G., Alam, N., Sikdar, N., Roy, B., Roychoudhury, S. and Panda, C.K., 2009. SH3GL2 and CDKN2A/2B loci are independently altered in early dysplastic lesions of head and neck: correlation with HPV infection and tobacco habit. The Journal of pathology 217, 408-19.

25. Gillison, M.L., Castellsague, X., Chaturvedi, A., Goodman, M.T., Snijders, P., Tommasino, M., Arbyn, M. and Franceschi, S., 2014. Eurogin Roadmap: comparative epidemiology of HPV infection and associated cancers of the head and neck and cervix. Int J Cancer 134, 497-507.

26. Gillison, M.L., Koch, W.M., Capone, R.B., Spafford, M., Westra, W.H., Wu, L., Zahurak, M.L., Daniel, R.W., Viglione, M., Symer, D.E., Shah, K.V. and Sidransky, D., 2000. Evidence for a causal association between human papillomavirus and a subset of head and neck cancers. J Natl Cancer Inst 92, 709-20.

27. Gupta, S., Kumar, P., Kaur, H., Sharma, N., Gupta, S., Saluja, D., Bharti, A.C. and Das, B., 2018. Constitutive activation and overexpression of NF-kappaB/c-Rel in conjunction with p50 contribute to aggressive tongue tumorigenesis. Oncotarget 9, 33011-33029.

28. Gupta, S., Kumar, P., Kaur, H., Sharma, N., Saluja, D., Bharti, A.C. and Das, B.C., 2015. Selective participation of c-Jun with Fra-2/c-Fos promotes aggressive tumor phenotypes and poor prognosis in tongue cancer. Scientific reports 5, 16811. 
29. Haraf, D.J., Nodzenski, E., Brachman, D., Mick, R., Montag, A., Graves, D., Vokes, E.E. and Weichselbaum, R.R., 1996. Human papilloma virus and p53 in head and neck cancer: clinical correlates and survival. Clin Cancer Res 2, 755-62.

30. Hatakeyama, H., Mizumachi, T., Sakashita, T., Kano, S., Homma, A. and Fukuda, S., 2014. Epithelial-mesenchymal transition in human papillomavirus-positive and -negative oropharyngeal squamous cell carcinoma. Oncology reports 32, 2673-9.

31. Jacobs, M.V., de Roda Husman, A.M., van den Brule, A.J., Snijders, P.J., Meijer, C.J. and Walboomers, J.M., 1995. Group-specific differentiation between high- and low-risk human papillomavirus genotypes by general primer-mediated PCR and two cocktails of oligonucleotide probes. Journal of clinical microbiology 33, 901-5.

32. Jalouli, J., Ibrahim, S.O., Mehrotra, R., Jalouli, M.M., Sapkota, D., Larsson, P.A. and Hirsch, J.M., 2010. Prevalence of viral (HPV, EBV, HSV) infections in oral submucous fibrosis and oral cancer from India. Acta Otolaryngol 130, 1306-11.

33. Karlsen, F., Kalantari, M., Chitemerere, M., Johansson, B. and Hagmar, B., 1994. Modifications of human and viral deoxyribonucleic acid by formaldehyde fixation. Laboratory investigation; a journal of technical methods and pathology 71, 604-11.

34. Kocjan, B.J., Hosnjak, L. and Poljak, M., 2015. Detection of alpha human papillomaviruses in archival formalin-fixed, paraffin-embedded (FFPE) tissue specimens. Journal of clinical virology : the official publication of the Pan American Society for Clinical Virology 76 S88-S97.

35. Kocjan, B.J., Maver, P.J., Hosnjak, L., Zidar, N., Odar, K., Gale, N. and Poljak, M., 2012. Comparative evaluation of the Abbott RealTime High Risk HPV test and INNO-LiPA HPV Genotyping Extra test for detecting and identifying human papillomaviruses in archival tissue specimens of head and neck cancers. Acta dermatovenerologica Alpina, Pannonica, et Adriatica 21, 73-5.

36. Kreimer, A.R., Clifford, G.M., Boyle, P. and Franceschi, S., 2005. Human papillomavirus types in head and neck squamous cell carcinomas worldwide: a systematic review. Cancer Epidemiol Biomarkers Prev 14, 467-75.

37. Kulkarni, S.S., Kulkarni, S.S., Vastrad, P.P., Kulkarni, B.B., Markande, A.R., Kadakol, G.S., Hiremath, S.V., Kaliwal, S., Patil, B.R. and Gai, P.B., 2011. Prevalence and distribution of high risk human papillomavirus (HPV) Types 16 and 18 in Carcinoma of cervix, saliva of patients with oral squamous cell carcinoma and in the general population in Karnataka, India. Asian Pacific journal of cancer prevention : APJCP 12, 645-8.

38. Lesnikova, I., Lidang, M., Hamilton-Dutoit, S. and Koch, J., 2010. Rapid, sensitive, type specific PCR detection of the E7 region of human papillomavirus type 16 and 18 from paraffin embedded sections of cervical carcinoma. Infectious agents and cancer 5, 2.

39. Lim, K., Moles, D.R., Downer, M.C. and Speight, P.M., 2003. Opportunistic screening for oral cancer and precancer in general dental practice: results of a demonstration study. Br Dent J 194, 497-502; discussion 493.

40. Machado, J., Reis, P.P., Zhang, T., Simpson, C., Xu, W., Perez-Ordonez, B., Goldstein, D.P., Brown, D.H., Gilbert, R.W., Gullane, P.J., Irish, J.C. and Kamel-Reid, S., 2010. Low prevalence of human papillomavirus in oral cavity carcinomas. Head Neck Oncol 2, 6.

41. Marur, S., D'Souza, G., Westra, W.H. and Forastiere, A.A., 2010. HPV-associated head and neck cancer: a virus-related cancer epidemic. The lancet oncology 11, 781-9.

42. McGurk, M. and Scott, S.E., 2010. The reality of identifying early oral cancer in the general dental practice. Br Dent J 208, 347-51.

43. Mishra, A., Bharti, A.C., Varghese, P., Saluja, D. and Das, B.C., 2006. Differential expression and activation of NF-kappaB family proteins during oral carcinogenesis: Role of high risk human papillomavirus infection. Int J Cancer 119, 2840-50.

44. Mitra, S., Banerjee, S., Misra, C., Singh, R.K., Roy, A., Sengupta, A., Panda, C.K. and Roychoudhury, S., 2007. Interplay between human papilloma virus infection and p53 gene alterations in head and neck squamous cell carcinoma of an Indian patient population. Journal of clinical pathology 60, 1040-7. 
45. Nagpal, J.K., Patnaik, S. and Das, B.R., 2002. Prevalence of high-risk human papilloma virus types and its association with P53 codon 72 polymorphism in tobacco addicted oral squamous cell carcinoma (OSCC) patients of Eastern India. International journal of cancer 97, 649-53.

46. Odida, M., de Sanjose, S., Quint, W., Bosch, X.F., Klaustermeier, J. and Weiderpass, E., 2008. Human Papillomavirus type distribution in invasive cervical cancer in Uganda. BMC infectious diseases 8,85 .

47. Odida, M., de Sanjose, S., Sandin, S., Quiros, B., Alemany, L., Lloveras, B., Quint, W., Kleter, B., Alejo, M., van Doorn, L.J. and Weiderpass, E., 2010. Comparison of human papillomavirus detection between freshly frozen tissue and paraffin embedded tissue of invasive cervical cancer. Infectious agents and cancer 5, 15 .

48. Pal, P., Raychowdhury, R., Basu, S., Gure, P.K., Das, S. and Halder, A., 2018. Cytogenetic and micronuclei study of human papillomavirus-related oral squamous cell carcinoma. Journal of oral and maxillofacial pathology : JOMFP 22, 335-340.

49. Palmer, E., Newcombe, R.G., Green, A.C., Kelly, C., Noel Gill, O., Hall, G., Fiander, A.N., Pirotte, E., Hibbitts, S.J., Homer, J. and Powell, N.G., 2014. Human papillomavirus infection is rare in nonmalignant tonsil tissue in the UK: implications for tonsil cancer precursor lesions. Int $\mathbf{J}$ Cancer 135, 2437-43.

50. Patel, K.R., Vajaria, B.N., Begum, R., Desai, A., Patel, J.B., Shah, F.D., Shukla, S.N. and Patel, P.S., 2014. Prevalence of high-risk human papillomavirus type 16 and 18 in oral and cervical cancers in population from Gujarat, West India. Journal of oral pathology \& medicine : official publication of the International Association of Oral Pathologists and the American Academy of Oral Pathology 43, 293-7.

51. QSS, 2010. Human Papillomavirus Laboratory Manual (First Edition). World Health Organization, Geneva.

52. Quintero, K., Giraldo, G.A., Uribe, M.L., Baena, A., Lopez, C., Alvarez, E. and Sanchez, G.I., 2013. Human papillomavirus types in cases of squamous cell carcinoma of head and neck in Colombia. Brazilian journal of otorhinolaryngology 79, 375-81.

53. Ragin, C.C. and Taioli, E., 2007. Survival of squamous cell carcinoma of the head and neck in relation to human papillomavirus infection: review and meta-analysis. Int J Cancer 121, 1813-20.

54. Ramshankar, V., Soundara, V.T., Shyamsundar, V., Ramani, P. and Krishnamurthy, A., 2014. Risk stratification of early stage oral tongue cancers based on HPV status and p16 immunoexpression. Asian Pacific journal of cancer prevention : APJCP 15, 8351-9.

55. Resnick, R.M., Cornelissen, M.T., Wright, D.K., Eichinger, G.H., Fox, H.S., ter Schegget, J. and Manos, M.M., 1990. Detection and typing of human papillomavirus in archival cervical cancer specimens by DNA amplification with consensus primers. J Natl Cancer Inst 82, 1477-84.

56. Sankaranarayanan, R., Ramadas, K., Thomas, G., Muwonge, R., Thara, S., Mathew, B., Rajan, B. and Trivandrum Oral Cancer Screening Study, G., 2005. Effect of screening on oral cancer mortality in Kerala, India: a cluster-randomised controlled trial. Lancet 365, 1927-33.

57. Sethi, S., Ali-Fehmi, R., Franceschi, S., Struijk, L., van Doorn, L.J., Quint, W., Albashiti, B., Ibrahim, M. and Kato, I., 2012. Characteristics and survival of head and neck cancer by HPV status: a cancer registry-based study. Int J Cancer 131, 1179-86.

58. Settle, K., Posner, M.R., Schumaker, L.M., Tan, M., Suntharalingam, M., Goloubeva, O., Strome, S.E., Haddad, R.I., Patel, S.S., Cambell, E.V., 3rd, Sarlis, N., Lorch, J. and Cullen, K.J., 2009.

Racial survival disparity in head and neck cancer results from low prevalence of human papillomavirus infection in black oropharyngeal cancer patients. Cancer Prev Res (Phila) 2, 77681.

59. Shi, W., Kato, H., Perez-Ordonez, B., Pintilie, M., Huang, S., Hui, A., O'Sullivan, B., Waldron, J., Cummings, B., Kim, J., Ringash, J., Dawson, L.A., Gullane, P., Siu, L., Gillison, M. and Liu, F.F., 2009. Comparative prognostic value of HPV16 E6 mRNA compared with in situ hybridization for human oropharyngeal squamous carcinoma. J Clin Oncol 27, 6213-21.

60. Shukla, S., Bharti, A.C., Mahata, S., Hussain, S., Hedau, S., Sharma, R., Pillai, M.R., Krishna, S., Chiplunkar, S., Tengaonkar, H. and Das, B.C., 2010a. Application of a Multiplex PCR to cervical 
Table 1: Clinicopathological characteristics of the patients with the anatomical sites of tissue collection.

\begin{tabular}{lcc}
\hline & Regional Dental Hospital & Tertiary Cancer Care Hospitals \\
\hline Cancer Types & Oral Cavity & Oral Cavity/Oropharyngeal \\
No. of Cases & $\mathbf{4 7}$ & $\mathbf{8 8}$ \\
Mean Age (SD; Years) & $46.6( \pm 13.4)$ & $54.3( \pm 10.8)$ \\
Male:Female Gender Ratio & $2.13: 1$ & $7.8: 1$ \\
Specimen Characteristics $(\downarrow)$ & Total & Total \\
Total cases & $\mathbf{4 7}$ & $\mathbf{8 8}$ \\
Oral Cavity & $\mathbf{4 7}$ & $\mathbf{5 5}(\mathbf{6 2 . 5})$ \\
Buccal Mucosa & $18(38.3)$ & 21 \\
Alveolar/ Gingival region & $15(31.9)$ & 16 \\
Buccal Vestibule & $4(8.5)$ & - \\
Retromolar Space & $3(6.4)$ & 3 \\
Floor of Mouth & $3(6.4)$ & 1 \\
Tongue & $4(8.5)$ & 14 \\
Oropharyngeal Region & - & $\mathbf{3 3}(\mathbf{3 7 . 5})$ \\
Posterior Tongue & - & 17 \\
Tonsil & - & 12 \\
Oropharynx & - & 4 \\
Histopathological Grading & & \\
WDSCC & $34(72.3)$ & $40(45.5)$ \\
MDSCC & $10(21.3)$ & $40(45.5)$ \\
PDSCC & $3(6.4)$ & $8(9.1)$ \\
TNM Staging & & $17(19.3)$ \\
Stage I & $3(6.4)$ & $3(3.4)$ \\
Stage II & $2(4.3)$ & $21(23.9)$ \\
Stage III & $16(34.0)$ & $47(53.4)$ \\
Stage IV & $26(53.3)$ & \\
\hline
\end{tabular}


Table 2: List of primers used, their amplicon size and the annealing temperatures.

\begin{tabular}{|c|c|c|c|c|c|}
\hline Primer set & Target & Primer Sequence & $\begin{array}{l}\text { Ampli. } \\
\text { Size } \\
\text { (bp) }\end{array}$ & $\begin{array}{l}\text { Ann. } \\
\text { Temp. } \\
\left({ }^{\circ} \mathrm{C}\right)\end{array}$ & Reference \\
\hline$\beta$-globin & $\begin{array}{l}\text { Human } \beta- \\
\text { globin }\end{array}$ & $\begin{array}{l}\text { Forward 5'-GAAGAGCCAAGGACAGGTAC-3' } \\
\text { Reverse 5'-CAACTTCATCCACGTTACACC-3' }\end{array}$ & 268 & 55 & $\begin{array}{l}\text { (Cai, Yu, } \\
\text { and Zhang, } \\
\text { 2001) }\end{array}$ \\
\hline p53 & $\begin{array}{l}\text { Human P53 } \\
\text { (Exon 5) }\end{array}$ & $\begin{array}{l}\text { Forward 5'-TACTCCCCTGCCCTCAACAA-3', } \\
\text { Reverse 5'-CATCGCTATCTGAGCAGCGC-3' }\end{array}$ & 184 & 61 & $\begin{array}{l}\text { (Yu et al., } \\
\text { 1999) }\end{array}$ \\
\hline $\begin{array}{l}\text { PGMY09 } \\
/ 11\end{array}$ & L1 HPV & $\begin{array}{l}\text { Forward } \\
\text { PGMY09-F 5'-CGTCCCAAAGGAAACTGATC-3', } \\
\text { PGMY09-G 5'-CGACCTAAAGGAAACTGATC-3' } \\
\text { PGMY09-H 5'-CGTCCAAAAGGAAACTGATC-3' } \\
\text { PGMY09-I 5'-GCCAAGGGGAAACTGATC-3' } \\
\text { PGMY09-J 5'-CGTCCCAAAGGATACTGATC-3' } \\
\text { PGMY09-K 5'-CGTCCAAGGGGATACTGATC-3', } \\
\text { PGMY09-L 5'-CGACCTAAAGGGAATTGATC-3', } \\
\text { PGMY09-M 5'-CGACCTAGTGGAAATTGATC-3' } \\
\text { PGMY09-N 5'-CGACCAAGGGGATATTGATC-3', } \\
\text { PGMY09-P 5'-GCCCAACGGAAACTGATC-3' } \\
\text { PGMY09-Q 5'-CGACCCAAGGGAAACTGGTC-3' } \\
\text { PGMY09-R 5'-CGTCCTAAAGGAAACTGGTC-3' } \\
\text { HMB01 5'-GCGACCCAATGCAAATTGGT-3' } \\
\text { Reverse } \\
\text { PGMY11-A 5'-GCACAGGGACATAACAATGG-3' } \\
\text { PGMY11-B 5'-GCGCAGGGCCACAATAATGG-3' } \\
\text { PGMY11-C 5'-GCACAGGGACATAATAATGG-3' } \\
\text { PGMY11-D 5'-GCCCAGGGCCACAACAATGG-3' } \\
\text { PGMY11-E 5'-GCTCAGGGTTTAAACAATGG-3' }\end{array}$ & 450 & 55 & $\begin{array}{l}(\mathrm{QSS}, \\
2010)\end{array}$ \\
\hline HLA & $\begin{array}{l}\text { Human } \\
\text { Leukocyte } \\
\text { Antigen } \\
\text { (HLA) }\end{array}$ & $\begin{array}{l}\text { Forward 5'-GTGGTGTAAACTTGTACCA-3' } \\
\text { Reverse 5'-GGTAGCAGCGGTAGAGTT-3' }\end{array}$ & 230 & 55 & \\
\hline GP5+/6+ & L1 HPV & $\begin{array}{l}\text { Forward 5'-TTGTTACTGTGGTAGATACTAC-3' } \\
\text { Reverse 5'-CTTATACTAAATGTCAAATAAAAA-3' }\end{array}$ & 127 & 55 & $\begin{array}{l}\text { (Jacobs et } \\
\text { al., 1995) }\end{array}$ \\
\hline HPV16 & URR & $\begin{array}{l}\text { Forward 5'-AAGGCCAACTAAATGTCAC-3' } \\
\text { Reverse 5'-CTGCTTTTATACTAACCGG-3' }\end{array}$ & 217 & 55 & $\begin{array}{l}\text { (Storey et } \\
\text { al., 1991) }\end{array}$ \\
\hline HPV18 & E6 & $\begin{array}{l}\text { Forward 5'-TGAGGTACCATTGGATATTT-3' } \\
\text { Reverse 5'-TAGCAAAAAGCTGCTTCACGC-3' }\end{array}$ & 100 & 55 & $\begin{array}{l}\text { (Shukla et } \\
\text { al., 2010a) }\end{array}$ \\
\hline
\end{tabular}


Table 3: Evaluation of protocols for DNA isolation from FFPE specimen in comparison to standard DNA isolation protocol (Proteinase K-Phenol Chloroform; PK-PC) performed on freshly-collected, paired tissues for their performance in detection of HPV infection in oral squamous cell carcinoma by PCR $[n=20(\%)]$.

\begin{tabular}{|c|c|c|c|c|c|c|c|c|c|c|c|c|c|c|}
\hline \multirow[b]{2}{*}{ 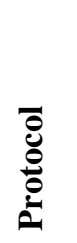 } & \multirow[b]{2}{*}{ 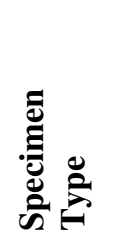 } & \multirow[b]{2}{*}{$\begin{array}{c}\text { DNA } \\
\text { Isolation }\end{array}$} & \multicolumn{4}{|c|}{ Internal Controls } & \multicolumn{4}{|c|}{ HPV Detection } & \multicolumn{4}{|c|}{ HR-HPV Types } \\
\hline & & & $\begin{array}{l}\beta \text {-globin } \\
(268 b p)\end{array}$ & $\begin{array}{l}\text { Conc. } \\
\text { (к) }\end{array}$ & $\begin{array}{c}\text { p53 } \\
(184 b p)\end{array}$ & $\begin{array}{l}\text { Conc. } \\
\text { (к) }\end{array}$ & $\begin{array}{c}\text { PGMY09/11 } \\
\text { (450bp) }\end{array}$ & $\begin{array}{l}\text { Conc. } \\
\text { (к) }\end{array}$ & $\begin{array}{c}\text { GP5+/6+ } \\
\text { (127bp) }\end{array}$ & $\begin{array}{l}\text { Conc. } \\
\text { (к) }\end{array}$ & $\begin{array}{c}\text { HPV16 } \\
\text { URR } \\
\text { (217bp) }\end{array}$ & $\begin{array}{l}\text { Conc. } \\
\text { (к) }\end{array}$ & $\begin{array}{c}\text { HPV18 } \\
\text { E6 } \\
\text { (100bp) }\end{array}$ & $\begin{array}{l}\text { Conc. } \\
\text { (к) }\end{array}$ \\
\hline $\mathrm{P} 1$ & $\begin{array}{c}\text { Fresh } \\
\text { Biopsy }\end{array}$ & PK-PC only & $\begin{array}{c}20 \\
(100)\end{array}$ & Ref. & $\begin{array}{c}20 \\
(100)\end{array}$ & Ref. & $\begin{array}{c}2 \\
(10)\end{array}$ & Ref. & $\begin{array}{c}4 \\
(20)\end{array}$ & Ref. & 0 & Ref. & $\begin{array}{c}2 \\
(10)\end{array}$ & Ref. \\
\hline $\mathrm{P} 2$ & FFPE & $\begin{array}{l}\text { Xylene \& } \\
\text { Rehydration } \\
\text { + PK-PC }\end{array}$ & 0 & 0 & $\begin{array}{c}4 \\
(20)\end{array}$ & $\begin{array}{c}20 \% \\
(0)\end{array}$ & 0 & 0 & 0 & 0 & 0 & NA & 0 & 0 \\
\hline P3 & FFPE & $\begin{array}{c}\text { Boiling in } \\
\text { Tween-20 } \\
(0.5 \% ; \\
10 \mathrm{~min} .)+ \\
\text { PK-PC }\end{array}$ & 0 & 0 & $\begin{array}{c}20 \\
(100)\end{array}$ & $\begin{array}{c}100 \% \\
(1)\end{array}$ & 0 & 0 & $\begin{array}{c}4 \\
(20)\end{array}$ & $\begin{array}{l}100 \% \\
(1)\end{array}$ & 0 & NA & $\begin{array}{c}2 \\
(10)\end{array}$ & $\begin{array}{c}100 \% \\
(1)\end{array}$ \\
\hline
\end{tabular}


Table 4: Results of PCR-based detection of HPV infection and its genotypes in oral cancer samples (N=50) from regional dental hospital using prospective (20) and retrospective (30) FFPE specimen and its comparison with HPV detection in freshly-collected oral and oropharyngeal tissues $\mathrm{N}=96$ ) from different tertiary cancer care hospitals.

\begin{tabular}{|c|c|c|c|c|c|}
\hline \multirow[b]{2}{*}{ PCR } & \multirow{2}{*}{$\begin{array}{c}\text { Dental } \\
\text { Hospital } \\
(\mathbf{n}=\mathbf{5 0}) \\
\text { (Oral only) }\end{array}$} & \multicolumn{4}{|c|}{ Tertiary Cancer Care Hospitals (Oral and Oropharyngeal cancers) } \\
\hline & & $\begin{array}{l}\text { Overall } \\
(\mathbf{n}=96)\end{array}$ & $\begin{array}{c}\text { RGCI } \\
(\mathbf{n}=60)\end{array}$ & $\begin{array}{l}\text { AIIMS } \\
(\mathbf{n}=\mathbf{2 0})\end{array}$ & $\begin{array}{l}\text { LHMC } \\
(n=16)\end{array}$ \\
\hline $\begin{array}{l}\text { Qualified Internal } \\
\text { Control } \\
\text { (Adequacy \%) }\end{array}$ & $\begin{array}{c}47 \\
(94.0 \%)\end{array}$ & $\begin{array}{c}88 \\
(91.7 \%)\end{array}$ & $\begin{array}{c}55 \\
(90.0 \%)\end{array}$ & $\begin{array}{c}19 \\
(95.0 \%)\end{array}$ & $\begin{array}{c}14 \\
(87.5 \%)\end{array}$ \\
\hline PGMY09/11 & $\begin{array}{c}5 \\
(11.0 \%)\end{array}$ & $\begin{array}{c}9 \\
(10.2 \%)\end{array}$ & $\begin{array}{c}9 \\
(16.3 \%)\end{array}$ & None & None \\
\hline GP5+/6+ & $\begin{array}{c}11 \\
(23.4 \%)\end{array}$ & $\begin{array}{c}20 \\
(22.7 \%)\end{array}$ & $\begin{array}{c}15 \\
(27.2 \%)\end{array}$ & None & $\begin{array}{c}5 \\
(35.7 \%)\end{array}$ \\
\hline HPV16 & None & $\begin{array}{c}12 \\
(60.0 \% *)\end{array}$ & $\begin{array}{c}8 \\
(53.3 \% *)\end{array}$ & None & $\begin{array}{c}4 \\
(80.0 \% *)\end{array}$ \\
\hline HPV18 & $\begin{array}{c}5 \\
(45.4 \% *)\end{array}$ & None & None & None & None \\
\hline
\end{tabular}

*Percentage with reference to total HPV positivity 
Table 5: Comparative evaluation of HPV positivity and HPV type 16 and HPV18-specific prevalence in oral and oro-pharyngeal SCC reported in regional dental and tertiary cancer care hospitals.

\begin{tabular}{|c|c|c|c|c|c|c|c|c|c|c|c|c|}
\hline & \multicolumn{4}{|c|}{ Regional Dental Hospital } & \multicolumn{8}{|c|}{$\begin{array}{l}\text { Tertiary Cancer Care Hospitals } \\
\end{array}$} \\
\hline Cancer Types & \multicolumn{4}{|c|}{ Oral Cavity } & \multicolumn{4}{|c|}{ Oral Cavity/Oropharyngeal } & \multicolumn{4}{|c|}{ Oral Cavity } \\
\hline No. of Cases & \multicolumn{4}{|c|}{47} & \multicolumn{4}{|c|}{88} & \multicolumn{4}{|c|}{55} \\
\hline Mean Age (SD; Years) & \multicolumn{4}{|c|}{$46.6( \pm 13.4)$} & \multicolumn{4}{|c|}{$54.3( \pm 10.8)$} & \multicolumn{4}{|c|}{$53.6( \pm 12.0)$} \\
\hline $\begin{array}{l}\text { Male:Female Gender } \\
\text { Ratio }\end{array}$ & \multicolumn{4}{|c|}{ 2.13:1 } & \multicolumn{4}{|c|}{ 7.8:1 } & \multicolumn{4}{|c|}{$8.33: 1$} \\
\hline \multicolumn{13}{|l|}{ Characteristics $(\downarrow)$} \\
\hline Total cases & 47 & $\begin{array}{c}11 \\
(23 \%) \\
\end{array}$ & - & $\begin{array}{c}5 \\
(10 \%) \\
\end{array}$ & 88 & $\begin{array}{c}20 \\
(22.7 \%) \\
\end{array}$ & $\begin{array}{c}12 \\
(13.6 \%) \\
\end{array}$ & - & 55 & $\begin{array}{c}7 \\
(12.7 \%) \\
\end{array}$ & $\begin{array}{c}3 \\
(5.4 \%) \\
\end{array}$ & - \\
\hline Oral Cavity & 47 & $\begin{array}{c}11 \\
(23 \%)\end{array}$ & - & $\begin{array}{c}5 \\
(10 \%)\end{array}$ & $\begin{array}{c}55 \\
(62.5)\end{array}$ & $\begin{array}{c}7 \\
(12.7 \%)\end{array}$ & $\begin{array}{c}3 \\
(5.5 \%)\end{array}$ & - & 55 & 7 & 3 & - \\
\hline Buccal Mucosa & $18(38.3)$ & $3(16.6)$ & - & $2(10.6)$ & 21 & 4 & 2 & - & $21(38.2)$ & $4(18)$ & 2 & - \\
\hline $\begin{array}{l}\text { Alveolar/ Gingival } \\
\text { region }\end{array}$ & $15(31.9)$ & $4(26.6)$ & - & 2 & 16 & 2 & - & - & $16(29.1)$ & $2(12)$ & - & - \\
\hline Buccal Vestibule & $4(8.5)$ & $1(25)$ & - & - & - & - & - & - & - & - & - & - \\
\hline Retromolar Space & $3(6.4)$ & $1(33)$ & - & 1 & 3 & - & - & - & $3(5.5)$ & - & - & - \\
\hline Floor of Mouth & $3(6.4)$ & $1(33)$ & - & - & 1 & - & - & - & $1(1.8)$ & - & - & - \\
\hline Tongue & $4(8.5)$ & $1(21)$ & - & - & 14 & 1 & 1 & - & $14(25.5)$ & 1 & 1 & - \\
\hline Oropharyngeal Region & - & - & - & - & $\begin{array}{l}33 \\
\quad(37.5)\end{array}$ & $\begin{array}{c}13 \\
(39.4 \%)\end{array}$ & $\begin{array}{c}9 \\
(27.27 \%)\end{array}$ & - & - & - & - & - \\
\hline Posterior Tongue & - & - & - & - & 17 & 9 & 7 & - & - & - & - & - \\
\hline Tonsil & - & - & - & - & 12 & 4 & 2 & - & - & - & - & - \\
\hline Oropharynx & - & - & - & - & 4 & - & - & - & - & - & - & - \\
\hline \multicolumn{13}{|l|}{$\begin{array}{l}\text { Histopathological } \\
\text { Grading }\end{array}$} \\
\hline WDSCC & $34(72.3)$ & $7(20.6)$ & - & 2 & $40(45.5)$ & $6(15)$ & 5 & - & $30(54)$ & $2(6.7)$ & 2 & - \\
\hline MDSCC & $10(21.3)$ & $3(30)$ & - & 2 & $40(45.5)$ & $11(27.5)$ & 4 & - & $23(41.8)$ & $5(21.7)$ & 1 & - \\
\hline PDSCC & $3(6.4)$ & $1(33)$ & - & 1 & $8(9.1)$ & $3(37.5)$ & 3 & - & $2(3.6)$ & - & - & - \\
\hline \multicolumn{13}{|l|}{ TNM Staging } \\
\hline Stage I & $3(6.4)$ & $1(33)$ & - & 1 & 17(19.3) & $4(23.5)$ & 3 & - & $15(27.3)$ & $2(13.3)$ & 1 & - \\
\hline Stage II & $2(4.3)$ & - & - & - & $3(3.4)$ & - & - & - & $3(5.5)$ & - & - & - \\
\hline Stage III & $16(34.0)$ & $3(18.8)$ & - & 1 & $21(23.9)$ & $3(14.3)$ & 3 & - & $14(25.5)$ & - & - & - \\
\hline Stage IV & $26(53.3)$ & $7(26.9)$ & - & 3 & $47(53.4)$ & $13(27.6)$ & 6 & - & $23(41.8)$ & $5(21.7)$ & 2 & - \\
\hline
\end{tabular}


Table 6: Representative HPV prevalence in oral cancer studies based on DNA isolated from FFPE specimens and its subsequent evaluation by amplification of different length fragments in PCR.

\begin{tabular}{|c|c|c|c|c|c|c|c|c|c|c|}
\hline $\begin{array}{c}\text { Country/Regi } \\
\text { on }\end{array}$ & $\begin{array}{l}\text { No. of } \\
\text { Cases }\end{array}$ & Specimen & $\begin{array}{l}\text { Paraffin } \\
\text { Removal }\end{array}$ & $\begin{array}{c}\text { DNA } \\
\text { Extraction }\end{array}$ & $\begin{array}{c}\% \\
\text { Adequacy } \\
(\#)\end{array}$ & $\begin{array}{c}\text { Max. } \\
\text { Amplified } \\
\text { Size (bp) }\end{array}$ & $\begin{array}{c}\text { HPV } \\
\text { detected } \\
(\%)\end{array}$ & $\begin{array}{c}\text { HPV16 } \\
(\%)\end{array}$ & $\begin{array}{c}\text { HPV18 } \\
(\%)\end{array}$ & $\begin{array}{l}\text { Refere } \\
\text { nce }\end{array}$ \\
\hline India & 91 & Oral & Heat & $\begin{array}{l}\text { Phenol } \\
\text { Chloroform }\end{array}$ & $\begin{array}{c}98 \\
\text { ( } \beta \text {-globin) }\end{array}$ & 450 & 73.6 & 41.8 & 47.3 & $\begin{array}{c}\text { (Balara } \\
\text { m et } \\
\text { al., } \\
1995)\end{array}$ \\
\hline USA & 66 & Oral & $\begin{array}{l}\text { Xylene and } \\
\text { Rehydration }\end{array}$ & $\begin{array}{l}\text { Phenol } \\
\text { Chloroform }\end{array}$ & NI & 168 & 18.0 & 16.0 & None & $\begin{array}{l}\text { (Haraf } \\
\text { et al., } \\
1996 \text { ) }\end{array}$ \\
\hline USA & 237 & Oral & $\begin{array}{l}\text { Xylene and } \\
\text { Rehydration }\end{array}$ & Qiamp-Kit & NI & NI & 29.0 & 29.0 & NA & $\begin{array}{l}\text { (Settle } \\
\text { et al., } \\
2009 \text { ) }\end{array}$ \\
\hline India & 62 & Oral & Direct & Qiagen-Kit & $\begin{array}{c}100 \\
(\beta \text {-actin })\end{array}$ & 450 & 24.0 & 16.0 & NA & $\begin{array}{l}\text { (Jalouli } \\
\text { et al., } \\
2010 \text { ) }\end{array}$ \\
\hline Slovenia & 60 & Oral & Direct & Qiamp-Kit & $\begin{array}{c}100 \\
(\beta \text {-actin })\end{array}$ & 65 & 8.3 & 8.3 & 0 & $\begin{array}{c}\text { (Kocja } \\
\text { n et al., } \\
\text { 2012) }\end{array}$ \\
\hline USA & 385 & Oral & $\begin{array}{c}\text { Tween-20 + } \\
\text { Boiling }\end{array}$ & $\begin{array}{l}\text { Phenol } \\
\text { Chloroform }\end{array}$ & NI & 65 & 29.4 & 23.5 & NA & $\begin{array}{l}\text { (Sethi } \\
\text { et al., } \\
2012 \text { ) }\end{array}$ \\
\hline Canada & 255 & Oral & $\begin{array}{l}\text { Xylene and } \\
\text { Rehydration }\end{array}$ & Kit-Method & $\begin{array}{c}83 \\
\text { ( } \beta \text {-globin) }\end{array}$ & 150 & 68.6 & 53.3 & NA & $\begin{array}{l}\text { (Thiba } \\
\text { udeau } \\
\text { et al., } \\
2013 \text { ) }\end{array}$ \\
\hline UK & 4,095 & Tonsil & Tween 20 & $\begin{array}{l}\text { Direct } \\
\text { Method }\end{array}$ & $\begin{array}{c}82.5 \\
\text { ( } \beta \text {-globin) }\end{array}$ & 142 & 0.00 & 0.00 & NA & $\begin{array}{l}\text { Palme } \\
\text { r et al., } \\
\text { 2014) }\end{array}$ \\
\hline
\end{tabular}




\begin{tabular}{|c|c|c|c|c|c|c|c|c|c|c|}
\hline India & 23 & Oral & Direct & Qiagen-Kit & $\begin{array}{c}100 \\
\text { (GluDH) }\end{array}$ & 200 & 13.0 & 13.0 & NA & $\begin{array}{c}\text { (Dhana } \\
\text { pal et } \\
\text { al., } \\
2015 \text { ) }\end{array}$ \\
\hline Brazil & 26 & Oral & $\begin{array}{l}\text { Xylene and } \\
\text { Rehydration }\end{array}$ & NI & $\begin{array}{c}88.46 \\
\text { ( } \beta \text {-globin) }\end{array}$ & 450 & 17.4 & NA & NA & $\begin{array}{l}\text { (Erhart } \\
\text { et al., } \\
\text { 2015) }\end{array}$ \\
\hline 29 Countries & 4022 & Oral & Direct & $\begin{array}{l}\text { Phenol } \\
\text { Chloroform }\end{array}$ & $\begin{array}{l}91.46 \\
\text { (Human } \\
\text { tubulin) }\end{array}$ & 65 & 15.0 & 12.0 & 0.2 & $\begin{array}{l}\text { (Castell } \\
\text { sague } \\
\text { et al., } \\
2016 \text { ) }\end{array}$ \\
\hline India & 50 & Oral & $\begin{array}{c}\text { Tween-20 + } \\
\text { Boiling }\end{array}$ & $\begin{array}{c}\text { Phenol } \\
\text { Chloroform }\end{array}$ & $\begin{array}{c}94 \\
(\mathrm{p53})\end{array}$ & 184 & 23.4 & $\mathbf{0}$ & 10 & $\begin{array}{l}\text { Presen } \\
\text { t Study }\end{array}$ \\
\hline
\end{tabular}




\section{Figure Legends}

Fig. 1 - Schematic representation of the study design. In the first phase, prospectively-collected, paired fresh and formalin-fixed tissues were evaluated for optimization of protocol for early detection of HPV infection in oral cancer cases at the regional dental hospital. A retrospective analysis of another 30 histopathologically-confirmed tissue blocks of OSCC from the same dental hospital was performed. In parallel, freshly-collected specimen from oral and oropharyngeal SCC reported at 3 different tertiary cancer care hospitals in the region [Rajiv Gandhi Cancer Institute (RGCI), All India Institute of Medical Sciences (AIIMS) and Lady Harding Medical College (LHMC)] were examined for HPV positivity and infection of the most frequent HR-HPV HPV16 and HPV18.

Fig. 2 - Schematic presentation of pre-treatment protocols utilized prior to DNA isolation from FFPE samples for detection of HPV by PCR in OSCC. Numbers in brackets indicate specific study referring the indicated protocol.

Fig. 3 - Determination of quality and quantity of genomic DNA isolated from paired freshly-collected biopsies using reference protocol P1 (A) and FFPE tissues by xylene-free protocol P3 (B). Ethidium bromide (EtBr)-stained $1 \%$ agarose gel pictures showing semi-quantitative assessment of genomic DNA isolated by two different extraction protocols from paired OSCC specimens (left panels). Lane M: Hind III digested $\lambda$ molecular weight marker; Lane 2 5: Biopsy samples DNA (1B-4B); FFPE samples DNA (1F-4F). Middle and left panels show representative $2 \%$ EtBrstained agarose gel pictures with qualitative assessment of DNA isolated from protocol P1 and P3 for amplification of $\beta$ - globin and p53 exon 5 by PCR. Lane M: HaeIII-digested $\Phi x 174$ DNA molecular weight marker.

Fig. 4 - HPVL1 Consensus PCRs with different fragment length amplification for detection of HPV in DNA from fresh and FFPE-OSCC tissues. Representative EtBr-stained gels showing PCR amplification of PGMY09/11(450bp) and GP5+/GP6+ (127bp) fragments using selected OSCC DNA isolated from paired fresh and

FFPE specimen using different protocols. A. Lane M: HaeIII-digested-Фx174 molecular weight marker, P - Positive Control, N - Negative Control, other lanes 4 - 7: HPV positive oral squamous cell carcinoma (OSCC) biopsy / FFPE genomic DNA.

Fig. 5 - Assessment of HR-HPV type 16 and 18 infection in OSCC FFPE tissues. FFPE DNA positive for PGMY09/11 and GP5+/GP6+ were subjected to HPV16 URR (217bp) and HPV18 E6 (100bp) amplification 
respectively. The PCR products were checked on $2 \%$ agarose gels stained with Ethidium Bromide and compared with HaeIII-digested Фx174 DNA as molecular weight marker.

Fig. 6 - HPV prevalence and type distribution in head and neck cancers tissues reported from different geographical regions of India. The regions covered are New Delhi (Gupta et al., 2018; Gupta et al., 2015; Mishra et al., 2006; Verma et al., 2017), Prayagraj, Uttar Pradesh (Chaudhary et al., 2010), Kolkata, West Bengal (Ghosh et al., 2009; Mitra et al., 2007; Pal et al., 2018), Cuttack, Odisha (Nagpal, Patnaik, and Das, 2002), Dharwad, Karnataka (Kulkarni et al., 2011), Mangalore, Karnataka (Bandhary et al., 2018), Bangalore, Karnataka (Dhanapal et al., 2015), Trivandrum, Kerala (Balaram et al., 1995), Chennai, Tamil Nadu (Ramshankar et al., 2014), Mumbai, Maharashtra (D'Costa et al., 1998), Ahmedabad, Gujrat (Patel et al., 2014). The detailed account of samples, specimen type, DNA isolation and other important features of these studies are outlined in Supplementary Table ST1. 

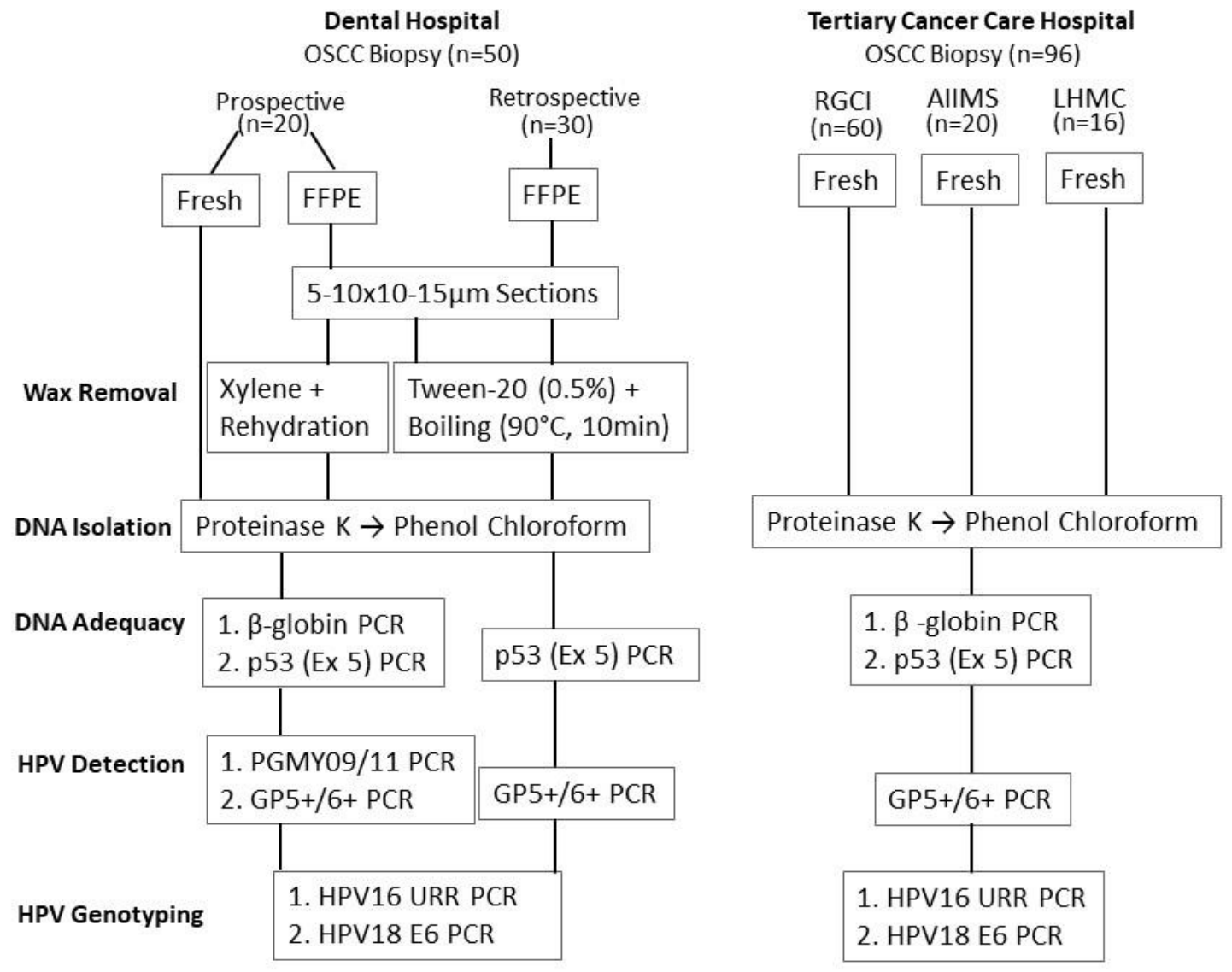

F1 
F2

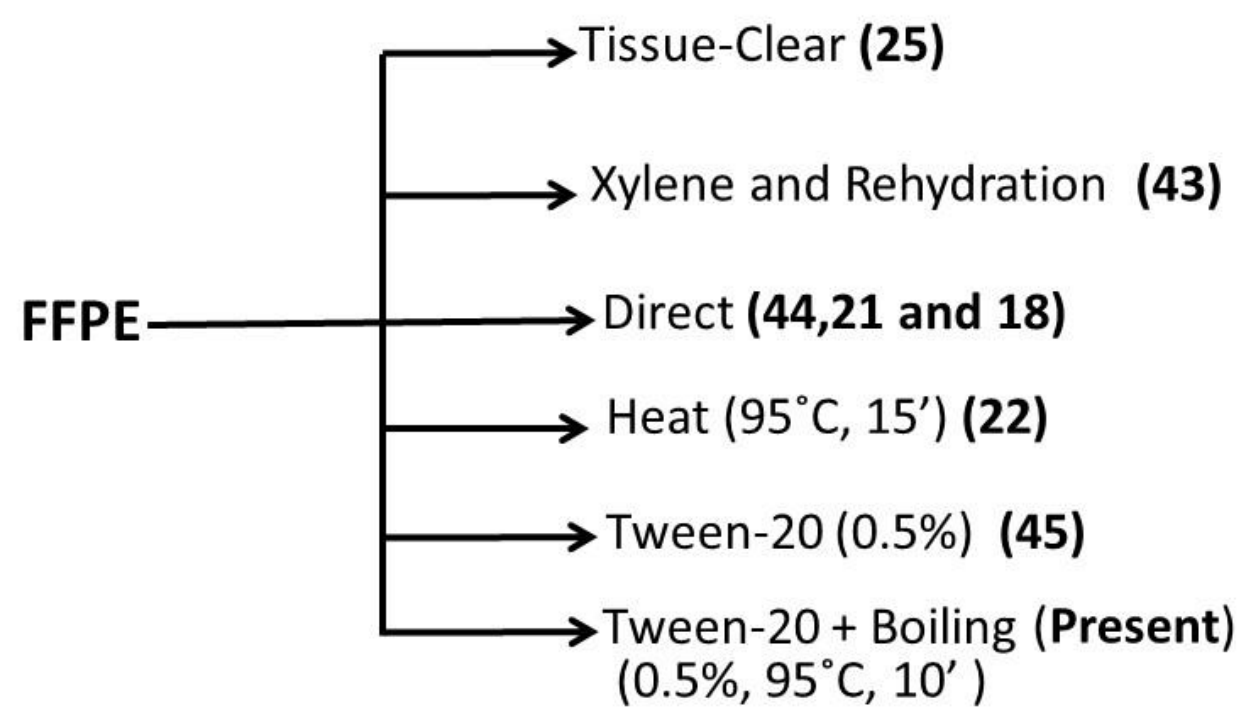


DNA

$\beta$-globin

p53
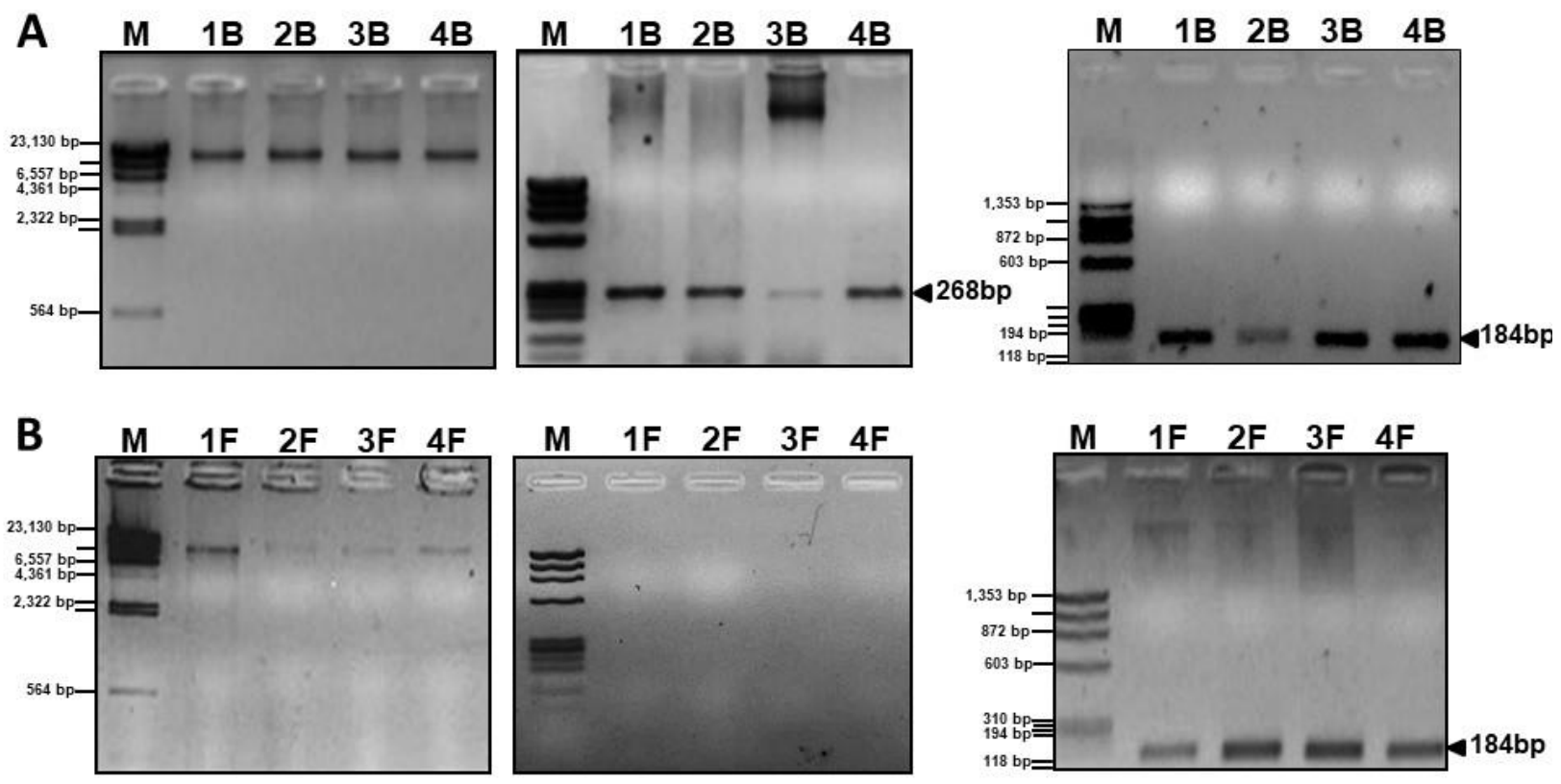


\section{A PGMY Primers}

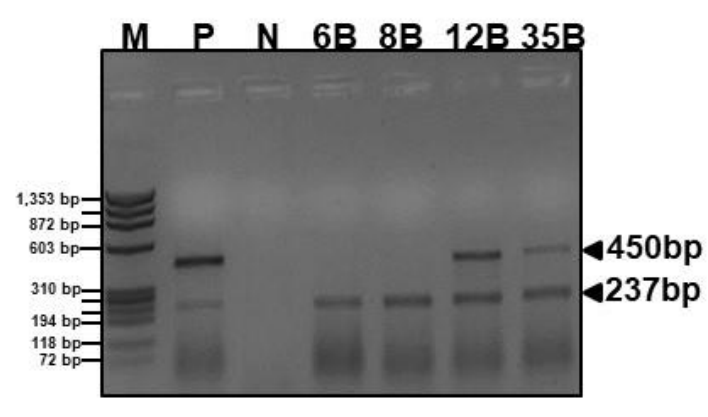

B

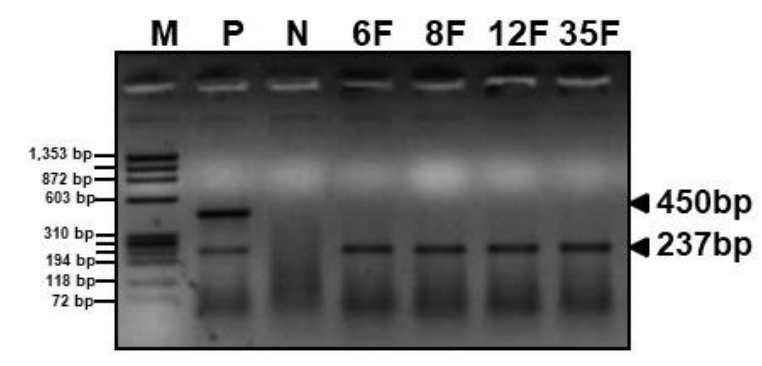

GP5/6 Primers
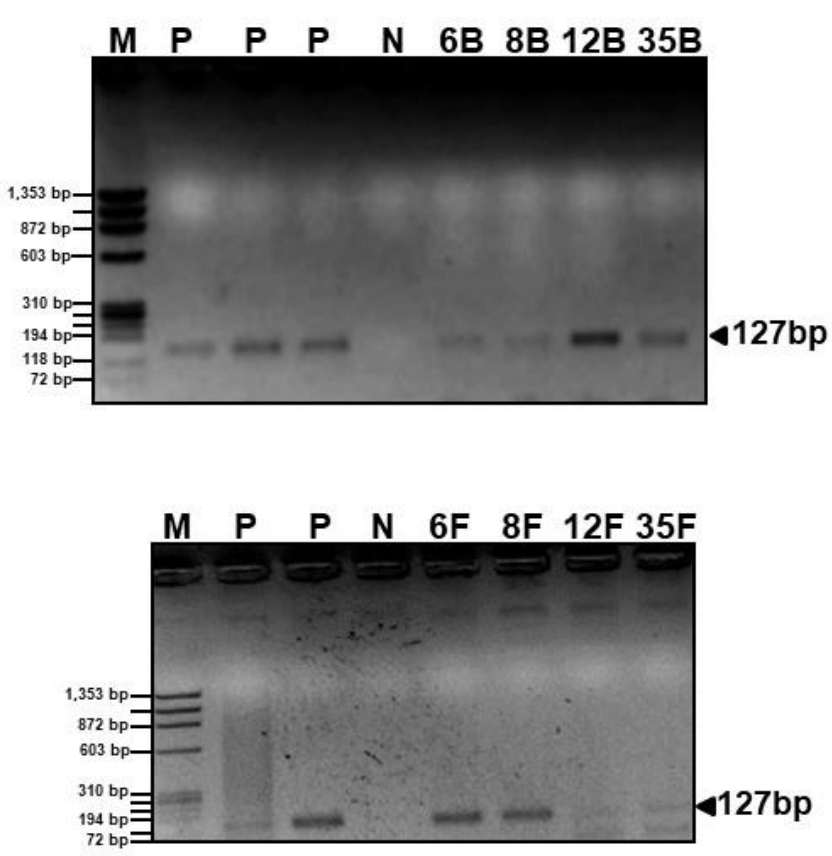
HPV 16 URR PCR

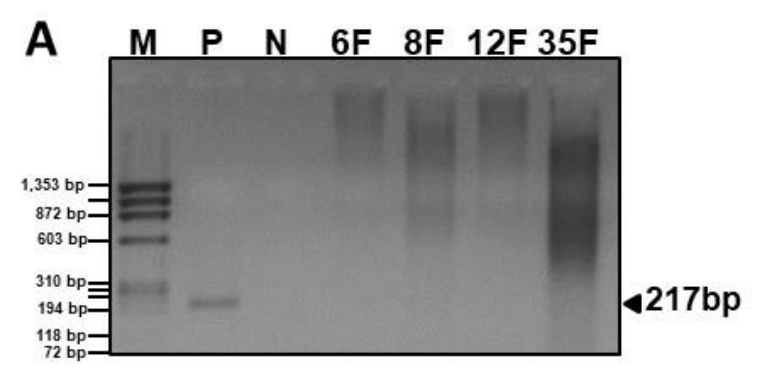

HPV18 E6 PCR

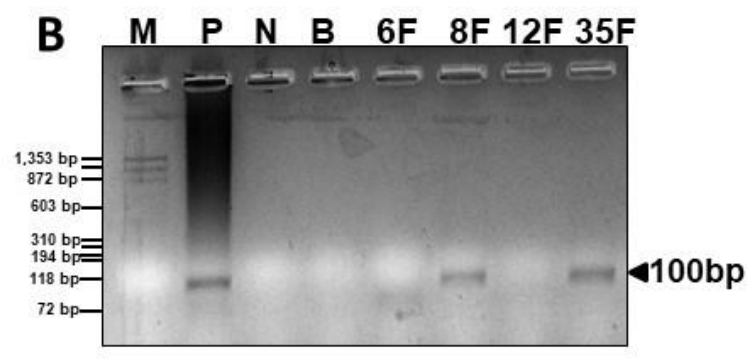




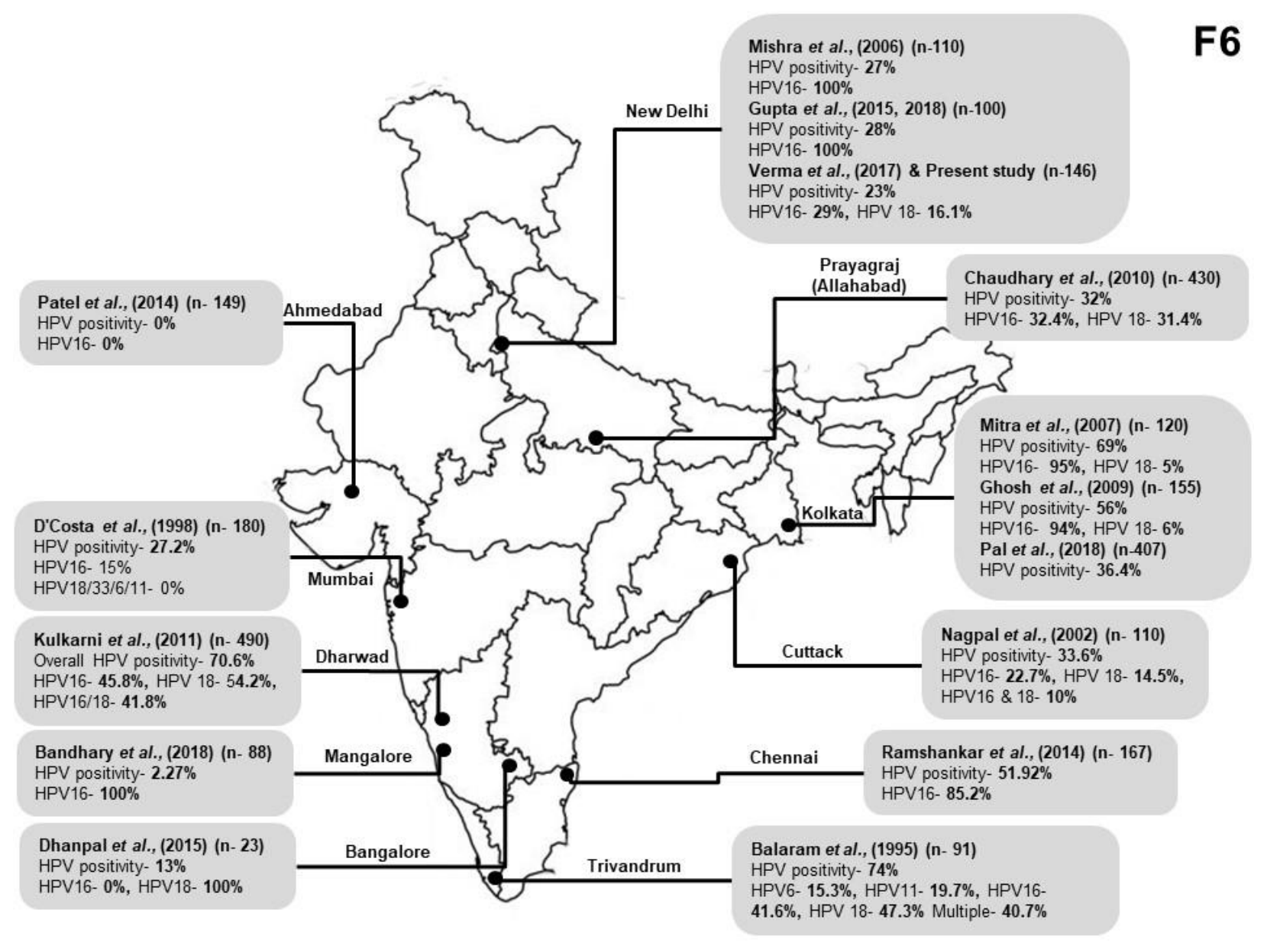


Supplementary Table ST1: HPV prevalence reported in Head and Neck cancer across different regions of India.

\begin{tabular}{|c|c|c|c|c|c|c|c|c|c|}
\hline S. No. & $\begin{array}{l}\text { Population/Re } \\
\text { gion }\end{array}$ & $\begin{array}{l}\text { No. of } \\
\text { Cases }\end{array}$ & $\begin{array}{l}\text { Sample } \\
\text { Type }\end{array}$ & Tissue characteristics (number) & $\begin{array}{l}\text { DNA isolation and quantity } \\
\text { used in PCR }\end{array}$ & $\begin{array}{l}\text { HPV Detection/Typing } \\
\text { Assay employed }\end{array}$ & $\begin{array}{l}\text { Overall HPV } \\
\text { Prevalence (\%) }\end{array}$ & $\begin{array}{l}\text { Type specific } \\
\text { prevalence }(\%)\end{array}$ & Reference \\
\hline 1. & $\begin{array}{l}\text { Trivandrum, } \\
\text { Kerala }\end{array}$ & 102 & $\begin{array}{l}\text { Snap frozen } \\
\text { biopsies (63), } \\
\text { FFPE (28) }\end{array}$ & $\begin{array}{l}\text { Oral cancer (n- 87): Buccal mucosa (60), } \\
\text { Tongue (11), Floor of mouth (6), L. alveolus } \\
\text { (10) } \\
\frac{\text { Precancerous (n- 15): SMF (4), Leucoplakia }}{\text { (5), others (6) }}\end{array}$ & $\begin{array}{l}\text { Biopsies: Phenol-Chloroform } \\
\text { Extraction (PCE) }(\mathbf{1 - 2} \boldsymbol{\mu l}) \\
\text { FFPE- Boiling } 15 \text { min before } \\
\text { PCE (1-2 } \mu \mathrm{l})\end{array}$ & $\begin{array}{l}\text { PCR (MY09/11, GP5/6, } \\
\text { GP17/18, Y1/Y2) } \\
\text { Type-specific PCR; } \\
\text { HPV6/11, HPV18 LCR } \\
\text { 1/2, HPV16BU/L) } \\
\end{array}$ & 74 & $\begin{array}{l}\text { HPV6 }(15.3) \\
\text { HPV11 (19.7) } \\
\text { HPV16 (41.6) } \\
\text { HPV18 (47.3) } \\
\text { Multiple (40.7) } \\
\end{array}$ & (Balaram et al., 1995) \\
\hline 2. & $\begin{array}{l}\text { Mumbai, } \\
\text { Maharashtra }\end{array}$ & 180 & Snap frozen & $\begin{array}{l}\text { Oral cancer (n- 100): Buccal mucosa (57), L. } \\
\text { alveolus (25), Tongue (14), Floor of mouth (2), } \\
\text { Hard palate (1), Maxilla (1). } \\
\text { Potentially malignant oral lesions (n- 80): } \\
\text { Leucoplakia (65), Lichen planus (6), Submucous } \\
\text { fibrosis (5), Erythroplakia(2), Melanoplakia (2) }\end{array}$ & $\begin{array}{l}\text { Phenol-Chloroform } \\
\text { Extraction (1 } 1 \mu \mathrm{g})\end{array}$ & $\begin{array}{l}\text { PCR (MY09/11); } \\
\text { Southern blotting (Radio } \\
\text { labelled HPV type } \\
\text { specific oligonucleotide) }\end{array}$ & 27.2 & $\begin{array}{l}\text { HPV16 (15) } \\
\text { HPV18/33/6/11 (0) }\end{array}$ & (D'Costa et al., 1998) \\
\hline 3. & $\begin{array}{l}\text { Cuttack, } \\
\text { Odisha }\end{array}$ & 136 & $\begin{array}{l}\text { Snap frozen } \\
\text { biopsies (78), } \\
\text { FFPE (32) }\end{array}$ & $\begin{array}{l}\text { Oral cancer (110): Cheek (56), Mandible (16), } \\
\text { Maxilla (13), Gum (6), Tongue (6), Lip (4), } \\
\text { Miscellaneous (9) } \\
\text { Normal (n- 26) }\end{array}$ & 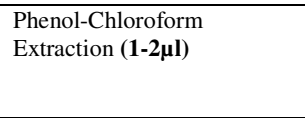 & $\begin{array}{l}\text { PCR } \\
\text { Southern blotting of L-1 } \\
\text { PCR products }\end{array}$ & 33.6 & $\begin{array}{l}\text { HPV16 (22.7) } \\
\text { HPV18 (14.5) } \\
\text { HPV16/18 (10) }\end{array}$ & $\begin{array}{l}\text { (Nagpal, Patnaik, and } \\
\text { Das, 2002) }\end{array}$ \\
\hline 4. & New Delhi & 110 & $\begin{array}{l}\text { Snap frozen } \\
\text { biopsies (55), } \\
\text { FFPE (55) }\end{array}$ & $\begin{array}{l}\text { Oral cancer (n- 66): Tongue (36), Mandibular } \\
\text { gingiva (7), Maxillary gingiva (4), Buccal } \\
\text { mucosa (12), Palate (3), Lips (4) } \\
\text { Premalignant (n- 34): Tongue (14), Mandibular } \\
\text { gingiva (4), Maxillary gingiva (3), Buccal } \\
\text { mucosa (6), Palate (2), Lips (5) } \\
\text { Normal healthy controls (n- 10): Tongue (4), } \\
\text { Mandibular gingiva (1), Buccal mucosa (3), Lips } \\
\text { (2) }\end{array}$ & 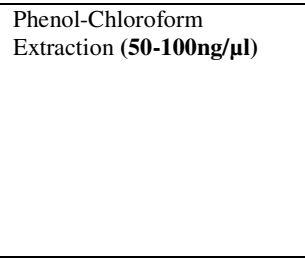 & PCR (MY09/11) & 27 & HPV16 (100) & (Mishra et al., 2006) \\
\hline 5. & $\begin{array}{l}\text { Kolkata, West } \\
\text { Bengal }\end{array}$ & 120 & $\begin{array}{l}\text { Snap frozen } \\
\text { biopsies }\end{array}$ & $\frac{\operatorname{HNSCC}(\mathrm{n}-92)}{\text { Leucoplakia }(\mathrm{n}-28)}$ & $\begin{array}{l}\text { Phenol-Chloroform } \\
\text { Extraction (NA) }\end{array}$ & $\begin{array}{l}\text { PCR (MY09/11) } \\
\text { Southern blotting }\end{array}$ & 69 & $\begin{array}{l}\text { HPV16 (95) } \\
\text { HPV18 (5) }\end{array}$ & (Mitra et al., 2007) \\
\hline 6. & $\begin{array}{l}\text { Kolkata, West } \\
\text { Bengal }\end{array}$ & 155 & $\begin{array}{l}\text { Snap frozen } \\
\text { biopsies, } \\
\text { FFPE }\end{array}$ & $\begin{array}{l}\text { HNSCC (n-155): Orofacial (13), Oral cavity } \\
\text { (133), Larynx (9) }\end{array}$ & NA & PCR (MY09/11) & 56 & $\begin{array}{l}\text { HPV16 (94) } \\
\text { HPV18 (6) }\end{array}$ & (Ghosh et al., 2009) \\
\hline 7. & $\begin{array}{l}\text { Allahabad, } \\
\text { Uttar Pradesh }\end{array}$ & 430 & FFPE & $\begin{array}{l}\text { Oral cancer (n-222) } \\
\underline{\text { OSMF }(\mathbf{n}-208)}\end{array}$ & $\begin{array}{l}\text { DNA tissue Kit (Qiagen Inc. } \\
\text { USA) }(\mathbf{5 0 - 1 0 0} \mathbf{~ n g / \mu l )}\end{array}$ & $\begin{array}{l}\text { PCR (MY09/11) } \\
\text { Hybrid capture-II (HC-II) }\end{array}$ & 32 & $\begin{array}{l}\text { HPV16 } \\
\text { PCR - (32.4) } \\
\text { HC-II - (31.4) } \\
\end{array}$ & (Chaudhary et al., 2010) \\
\hline 8. & $\begin{array}{l}\text { Dharwad, } \\
\text { Karnataka }\end{array}$ & 430 & Saliva rinse & $\begin{array}{l}\frac{\text { Oral cancer }(\mathbf{n}-34)}{\text { Normal }(\mathbf{n}-396)} \\
\end{array}$ & $\begin{array}{l}\text { FFPE- DNA tissue Kit } \\
\text { (Qiagen Inc. USA) } \\
\text { Saliva- Phenol-Chloroform } \\
\text { Extraction (75-150ng/ } \mathbf{\mu l}) \\
\end{array}$ & PCR (MY09/11) & 70.6 & $\begin{array}{l}\text { HPV16 (45.8) } \\
\text { HPV18 (54.2) } \\
\text { HPV16/18 (41.8) }\end{array}$ & (Kulkarni et al., 2011) \\
\hline 9. & $\begin{array}{l}\text { Ahmedabad, } \\
\text { Gujarat }\end{array}$ & 97 & $\begin{array}{l}\text { Snap frozen } \\
\text { biopsies }\end{array}$ & Oral cancer (n-97) & $\begin{array}{l}\text { DNA mini kit } \\
\text { (Qiagen, CA, USA) (100 } \\
\mathbf{n g} / \mathbf{u l})\end{array}$ & PCR (Type specific) & 0 & 0 & (Patel et al., 2014) \\
\hline 10. & $\begin{array}{l}\text { Chennai, Tamil } \\
\text { Nadu }\end{array}$ & 167 & FFPE & Tongue cancer (n- 167) & $\begin{array}{l}\text { High Pure FFPET DNA } \\
\text { isolation kit (Roche, } \\
\text { Mannheim, Germany) (100 } \\
\mathbf{n g} / \mathbf{M l})\end{array}$ & $\begin{array}{l}\text { PCR (GP5+/6+, } \\
\text { SPF10F/R), } \\
\text { Type specific primer }\end{array}$ & 51.9 & HPV16 (85.2) & (Ramshankar et al., 2014) \\
\hline 11. & $\begin{array}{l}\text { Bangalore, } \\
\text { Karnataka }\end{array}$ & 23 & FFPE & Oral cancer $(n-23)$ & Qiagen miniamp -Kit (NA) & $\begin{array}{l}\text { PCR- HPV16 E7, HPV18 } \\
\text { E1 }\end{array}$ & 13 & $\begin{array}{l}\text { HPV16 (NIL) } \\
\text { HPV18 (100) }\end{array}$ & $\{$ Dhanapal, $2015 \# 21\}$ \\
\hline 12. & New Delhi & 100 & $\begin{array}{l}\text { Snap frozen } \\
\text { biopsies }\end{array}$ & $\begin{array}{l}\text { Tongue Cancer (n-50) } \\
\text { Precancer (n-20) } \\
\text { Adjacent control (n-30) }\end{array}$ & $\begin{array}{l}\text { Phenol-Chloroform } \\
\text { Extraction }(\mathbf{1 0 0 n g} / \boldsymbol{\mu l})\end{array}$ & $\begin{array}{l}\text { PCR (MY09/11) } \\
\text { PGMY-Reverse Line Blot } \\
\text { assay (RLB) }\end{array}$ & 28 & HPV16 (100) & $\begin{array}{l}\text { (Gupta et al., } \\
\text { 2015)\{Gupta, } 2018 \# 185\}\end{array}$ \\
\hline 13. & New Delhi & 146 & $\begin{array}{l}\text { Snap fresh } \\
\text { biopsies, } \\
\text { FFPE }\end{array}$ & $\begin{array}{l}\text { Oral cancer (n- 102) } \\
\text { Oropharyngeal (n- 33) }\end{array}$ & $\begin{array}{l}\text { Phenol-Chloroform } \\
\text { Extraction }(\mathbf{1 0 0 n g} / \mathbf{\mu l})\end{array}$ & $\begin{array}{l}\text { PCR (GP5+/6+), Type } \\
\text { specific primer } \\
\text { HPV16\&18 }\end{array}$ & 23 & $\begin{array}{l}\text { HPV16 (29) } \\
\text { HPV18 (16.1) }\end{array}$ & (Verma et al., 2017) \\
\hline
\end{tabular}




\begin{tabular}{|c|c|c|c|c|c|c|c|c|c|}
\hline 14. & $\begin{array}{l}\text { Mangalore, } \\
\text { Karnataka }\end{array}$ & 88 & $\begin{array}{l}\text { Snap frozen } \\
\text { biopsies }\end{array}$ & $\begin{array}{l}\text { HNSCC (n-88): Oropharyngeal and oral (57), } \\
\text { Laryngeal (11), Hypopharyngeal (20) }\end{array}$ & $\begin{array}{l}\text { Dneasy minikit (Qiagen } \\
\text { Valencia, CA) (20-300ng/ } \mathbf{\mu l})\end{array}$ & $\begin{array}{l}\text { PCR (MY09/11, } \\
\text { GP5+/6+), Type specific } \\
\text { primer }\end{array}$ & 2.3 & HPV16 (100) & (Bandhary et al., 2018) \\
\hline 15. & $\begin{array}{l}\text { Kolkata, West } \\
\text { Bengal }\end{array}$ & 407 & - & $\begin{array}{l}\text { Oral cancer }(n-104) \\
\text { Premalignant oral lesions (n- 103) } \\
\text { Control (n- 200) }\end{array}$ & $\begin{array}{l}\text { DNA Mini Kit (Qiagen) } \\
\text { (NA) }\end{array}$ & PCR (MY09/11) & 36.4 & - & (Pal et al., 2018) \\
\hline
\end{tabular}

Abbreviations: FFPE- Formalin fixed and paraffin embedded, HNSCC- Head and Neck Squamous Cell Carcinoma, HPV- Human Papillomavirus, NA-

Not Available, PCR- Polymerase Chain Reaction, OSMF- Oral Sub mucous Fibrosis.

\section{References:}

Balaram, P., Nalinakumari, K.R., Abraham, E., Balan, A., Hareendran, N.K., Bernard, H.U. and Chan, S.Y., 1995. Human papillomaviruses in 91 oral cancers from Indian betel quid chewers--high prevalence and multiplicity of infections. International journal of cancer 61, 450-4.

Bandhary, S.K., Shetty, V., Saldanha, M., Gatti, P., Devegowda, D., R, P.S. and Shetty, A.K., 2018. Detection of Human Papilloma Virus and Risk Factors among Patients with Head and Neck Squamous Cell Carcinoma Attending a Tertiary Referral Centre in South India. Asian Pacific journal of cancer prevention : APJCP 19, 1325-1330.

Chaudhary, A.K., Pandya, S., Mehrotra, R., Bharti, A.C., Singh, M. and Singh, M., 2010. Comparative study between the Hybrid Capture II test and PCR based assay for the detection of human papillomavirus DNA in oral submucous fibrosis and oral squamous cell carcinoma. Virology journal 7, 253.

D'Costa, J., Saranath, D., Dedhia, P., Sanghvi, V. and Mehta, A.R., 1998. Detection of HPV-16 genome in human oral cancers and potentially malignant lesions from India. Oral oncology 34, 413-20.

Ghosh, A., Ghosh, S., Maiti, G.P., Sabbir, M.G., Alam, N., Sikdar, N., Roy, B., Roychoudhury, S. and Panda, C.K., 2009. SH3GL2 and CDKN2A/2B loci are independently altered in early dysplastic lesions of head and neck: correlation with HPV infection and tobacco habit. The Journal of pathology 217, 408-19.

Gupta, S., Kumar, P., Kaur, H., Sharma, N., Saluja, D., Bharti, A.C. and Das, B.C., 2015. Selective participation of c-Jun with Fra-2/c-Fos promotes aggressive tumor phenotypes and poor prognosis in tongue cancer. Scientific reports 5, 16811.

Kulkarni, S.S., Kulkarni, S.S., Vastrad, P.P., Kulkarni, B.B., Markande, A.R., Kadakol, G.S., Hiremath, S.V., Kaliwal, S., Patil, B.R. and Gai, P.B., 2011. Prevalence and distribution of high risk human papillomavirus (HPV) Types 16 and 18 in Carcinoma of cervix, saliva of patients with oral squamous cell carcinoma and in the general population in Karnataka, India. Asian Pacific journal of cancer prevention : APJCP 12, 645-8.

Mishra, A., Bharti, A.C., Varghese, P., Saluja, D. and Das, B.C., 2006. Differential expression and activation of NF-kappaB family proteins during oral carcinogenesis: Role of high risk human papillomavirus infection. International journal of cancer 119, 2840-50.

Mitra, S., Banerjee, S., Misra, C., Singh, R.K., Roy, A., Sengupta, A., Panda, C.K. and Roychoudhury, S., 2007. Interplay between human papilloma virus infection and p53 gene alterations in head and neck squamous cell carcinoma of an Indian patient population. Journal of clinical pathology 60, 1040-7.

Nagpal, J.K., Patnaik, S. and Das, B.R., 2002. Prevalence of high-risk human papilloma virus types and its association with P53 codon 72 polymorphism in tobacco addicted oral squamous cell carcinoma (OSCC) patients of Eastern India. International journal of cancer 97, 64953. 
Pal, P., Raychowdhury, R., Basu, S., Gure, P.K., Das, S. and Halder, A., 2018. Cytogenetic and micronuclei study of human papillomavirus-related oral squamous cell carcinoma. Journal of oral and maxillofacial pathology : JOMFP 22, 335-340.

Patel, K.R., Vajaria, B.N., Begum, R., Desai, A., Patel, J.B., Shah, F.D., Shukla, S.N. and Patel, P.S., 2014. Prevalence of high-risk human papillomavirus type 16 and 18 in oral and cervical cancers in population from Gujarat, West India. Journal of oral pathology \& medicine : official publication of the International Association of Oral Pathologists and the American Academy of Oral Pathology 43, 293-7.

Ramshankar, V., Soundara, V.T., Shyamsundar, V., Ramani, P. and Krishnamurthy, A., 2014. Risk stratification of early stage oral tongue cancers based on HPV status and p16 immunoexpression. Asian Pacific journal of cancer prevention : APJCP 15, 8351-9.

Verma, G., Vishnoi, K., Tyagi, A., Jadli, M., Singh, T., Goel, A., Sharma, A., Agarwal, K., Prasad, S.C., Pandey, D., Sharma, S., Mehrotra, R., Singh, S.M. and Bharti, A.C., 2017. Characterization of key transcription factors as molecular signatures of HPV-positive and HPV-negative oral cancers. Cancer medicine 6, 591-604. 